\title{
QUATERNARY PALEOECOLOGY OF FUEGO-PATAGONIA
}

\section{J. HEUSSER}

\begin{abstract}
The paleoecology of Quaternary events in Fuego-Patagonia derives from biogenic deposits emplaced before, during, and following the last glacial maximum. Paleoecological data center on the palynology of stratigraphic sections of (1) biogenic beds in a proglacial delta of finite and infinite age at Lago Fagnano, and of (2) selected sites of radiocarbondated, late-glacial and postglacial, mire/lacustrine deposits at Puerto Harberton, Lago Fagnano, and Bahía Inútil in Fuegia and at Punta Arenas and Torres del Paine in Patagonia. Events embrace noteworthy sequences involving vegetation and climate, atmospheric circulation, fire, human presence, land-sea level relations, and volcanism.

Data from peaty horizons in the Pleistocene delta at Lago Fagnano, dated at about 40000 and $>58000 \mathrm{yr} \mathrm{BP}$, indicate treeless steppe/tundra under a cold, dry, interstadial climate. Younger deposits, formed following the last glacial maximum dated at $>16590$ in the Estrecho de Magallanes and $>14640 \mathrm{yr}$ BP in Canal Beagle, show climatically variable, lateglacial episodes of woodland - steppe/tundra interaction. In the warmer early Holocene, progressive development of closed forest replacing open woodland and steppe, is a general feature of the vegetation; evident after $5000 \mathrm{yr} \mathrm{BP}$, under a cool-temperate, more humid climate, are the increased presence of closed forest and the spread of mires on the landscape. Apparent from the Holocene vegetation pattern is the greater frequency/intensity of cyclonic storms of the prevailing westerlies crossing Fuego-Patagonia after $5000 \mathrm{yr}$ BP.

Charcoal, in addition to fossil pollen in the records, is ascribed to Paleoindian burning, as purposely practiced during hunting to congregate game. On Isla Grande de Tierra del Fuego, where volcanic activity and lightning are not considered to be causal agents of fire, burning attributed to Paleoindian hunters is traceable from late-glacial charcoal remains as early as 13280 yr BP. Fires in Fuego-Patagonia, judged from the frequency of charcoal, were commonplace in the early Holocene and later more occasional, possiby reflecting changes in size and routes of migration in human populations.
\end{abstract}

\section{INTRODUCTION}

Fuego-Patagonia was introduced to the scientific world by the writings of Charles Darwin, following his travels and discoveries in 18311836 , while acting as naturalist on board the H.M.S. Beagle. Discovered in 1520 by Fernão de Magalhães during his circumnavigation of the globe, Fuegia or Tierra del Fuego (land of fire) gained its name from the many fires in native settlements along the shores of the present Estrecho de Magallanes, seen at the time of discovery. The strait separates Patagonia of continental South America from Fuegia, that is, Isla Grande de Tierra del Fuego and its adjoining archipelago (Fig. 1). Later exploration, notably by Carl Skottsberg (1910), Carl C. Caldenius (1932), and V̈ainö Auer (1933, 1956, 1958, 1974), established a foundation for modern scientific inquiry of Quaternary events and paleoecology.
Fuego-Patagonia, $<1000 \mathrm{~km}$ from Antarctica, was subject to repeated glaciation and cold stadial climate, interrupted by deglaciation and milder interstades, during past ice ages. As a result, the region is rich in deposits relating to a broad range of topics, including glaciation, climate, atmospheric circulation, vegetation, human presence, fire history, volcanism, and land-sea level changes. Modern radiometric methods have provided a means of correlation of the deposits by chronologically ordering the important events. Datable biogenic sequences in Fuegia and Patagonia, however, are mostly applicable to deglaciation following the last glacial maximum. This chapter, for the most part, covers radiocarbon-datable material related to this interval, at the same time, amplifying and further discussing paleoecological data presented recently in the works of RABASSA et al. (1992) and MARKGRAF (1993). 


\section{FUEGO-PATAGONIA}

The strikig feature of Fuego-Patagonia is the Cordillera de los Andes, which curves southeastward in southern Patagonia, lowering in altitude from over $3000 \mathrm{~m}$ at Torres del Paine to $500 \mathrm{~m}$ or less in the eastern part of Isla Grande (Fig. 1). Glaciers and ice fields at higher altitudes in the Andes are of considerable extent in Fuegia in the Cordillera Darwin (Fig. 2 ), where the snowline at around $600 \mathrm{~m}$ on western slopes rises to $1000 \mathrm{~m}$ to the east (MERCER, 1967). The steep descent of the Andes to the drowned coast and countless islands on the Pacific side contrasts the more gradual incline of the Atlantic slope with its occasional low hills and broad river drainage.

Older plutonic rocks of the Andes, including granite and volcanics, eastward juxtapose younger metamorphic and sedimentary formations (CAMINOS, 1980; CODIGNOTTO \& MALUMIAN, 1981). Tertiary basins of marine, estuarine, and deltaic sediments of Eocene-Miocene age extensively underlie PlioPleistocene glacial deposits on the Atlantic slope (Fig. 3; RUSSO et al., 1980; MEGLIOLI, 1992). Coincident with plate spreading, involving tectonic movement of the Antarctic, Scotia, and South American plates, volcanic eruptions during the Quaternary have occurred in the Andes (sources of at least three widespread tephra layers) and in sectors to the east (Fig. 4), except on Isla Grande, where no volcanoes occur (STERN, 1990). In addition, relative positions of land and sea in Fuego-Patagonia (PORTER et al., 1984; RABASSA et al., 1986; RUTTER, et al., 1989) were higher by $>40 \mathrm{~m}$ on the Atlantic coast in the Pleistocene, and during the middle Holocene, $>3 \mathrm{~m}$ higher along the Estrecho de Magallanes and $>8 \mathrm{~m}$ on Canal Beagle.

Oceanic climate developed by the prevailing southern westerlies is characteristic of the Andean cordillera, whereas downslope toward the Atlantic, conditions are drier and increasingly continental. Precipitation along the gradient decreases from $>7000$ to $200-300 \mathrm{~mm} \mathrm{yr}^{-1}$; mean January (summer) isotherms range from $8^{\circ}$ along the outer Pacific coast of Fuegia to $14^{\circ} \mathrm{C}$ in Patagonia (PROHASKA, 1976). Throughout the region, wind, often associated with squalls and rapidly successive storm passages, is almost an omnipresent factor, eroding the landscape and shaping the vegetation.

Forest formations (Fig. 1) are spread over much of the Andes below an altitude of 500$600 \mathrm{~m}$ (PISANO, 1977; MOORE, 1983). At their upper altitudinal limit, trees are structural- ly reduced to dense krummholz, which makes sharp contact with the Andean Tundra. Where precipitation averages $400-600 \mathrm{~mm} \mathrm{yr}^{-1}$, Subantarctic Deciduous Forest (Fig. 5) of southern beech, Nothofagus pumilio and N. antarcti$c a$, obtains; Subantarctic Evergreen Forest, dominated by $N$. betuloides, prevails with higher levels of moisture, mainly on contiguous ground facing the Pacific. The outer headlands and islands of the western coast with excessively large amounts of precipitation support Magellanic Moorland in which Donatia fascicularis, Astelia pumila, and Oreobolus obtusangulus are the principal species.

According to MOORE (1975, 1983), Andean tundra includes communities of heath, both cushion heath (Bolax gummifera) and dwarf shrub heath (Empetrum rubrum), feldmark (Moschopsis rosulata, Nassauvia lagascae), and rich "meadow"(Abrotanella linearifolia, Caltha appendiculata, and Plantago barbata with grass and sedge species). Wind, water, and substrate are significant factors controlling composition and distribution of tundra vegetation.

Patagonian Steppe (Fig. 1) is expansive beyond the forest border of Subantarctic Deciduous Forest on the Atlantic side of Fuego-Patagonia. It develops through an ecotone, or tension zone, of dwindling, depauperate Nothofagus antarctica woodland (Figs. 6 and 7). Communities consisting of grassland, scrub, and heath are distinguishable but floristically diverse (MOORE, 1983), their occurrence and composition dictated by moisture and by soil conditions.

Precipitation in the Fuegian steppe averages 300-400 mm yr ${ }^{-1}$ and decreases to around $200 \mathrm{~mm}$ in Patagonia. Grassland on well drained upland soils is typically of Festuca gracilli$m a$ (Fig. 8); drainage courses, by comparison, contain more mesic grasses, together with sedges and rushes. Scrub of Chiliotrichum diffusum is a feature of Nothofagus woodland; scrub of Lepidophyllum cupressiforme is identified with coastal and inland sandy soils. Heath communities in the drier parts of FuegoPatagonia include Empetrum rubrum on acid soil and Nardophyllum bryoides on gravel.

\section{PLIO-PLEISTOCENE GLACIATION}

CALDENIUS (1932) placed the limit of glaciers beyond the Andean front at the time of the maximum glaciation in southern Patagonia and recognized a virtually complete ice cover of Fuegia. During maximum and subsequent glaciations, major routes for ice flowing from the Cordillera Darwin were northeastward, 
$-40^{\circ}$

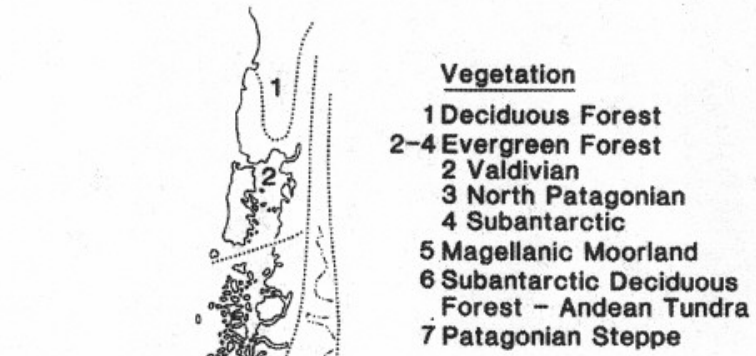

$50^{\circ}$

$45^{\circ}$

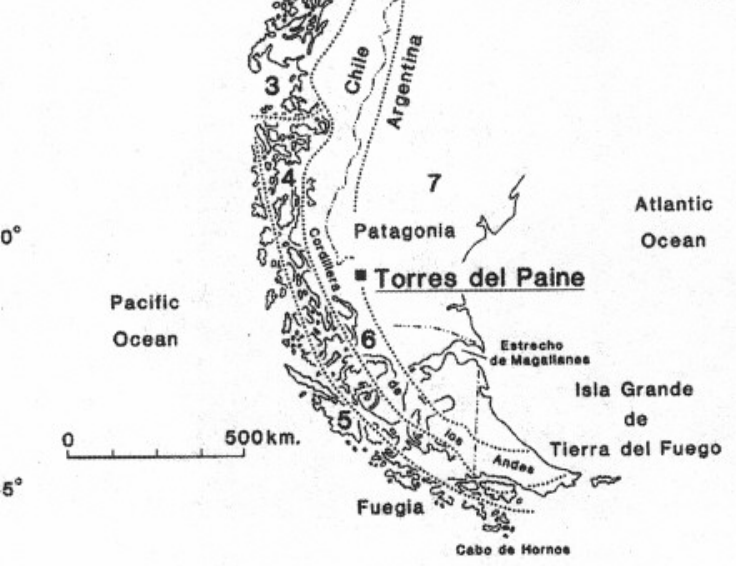

$80^{\circ}$

$70^{\circ}$

$60^{\circ}$

FIGURE 1 - Location of Fuegia and Patagonia, including site of Torres del Paine, in relation to vegetation zones (SCHMITHÜSEN, 1960; PISANO, 1977, 1981; MOORE, 1983).

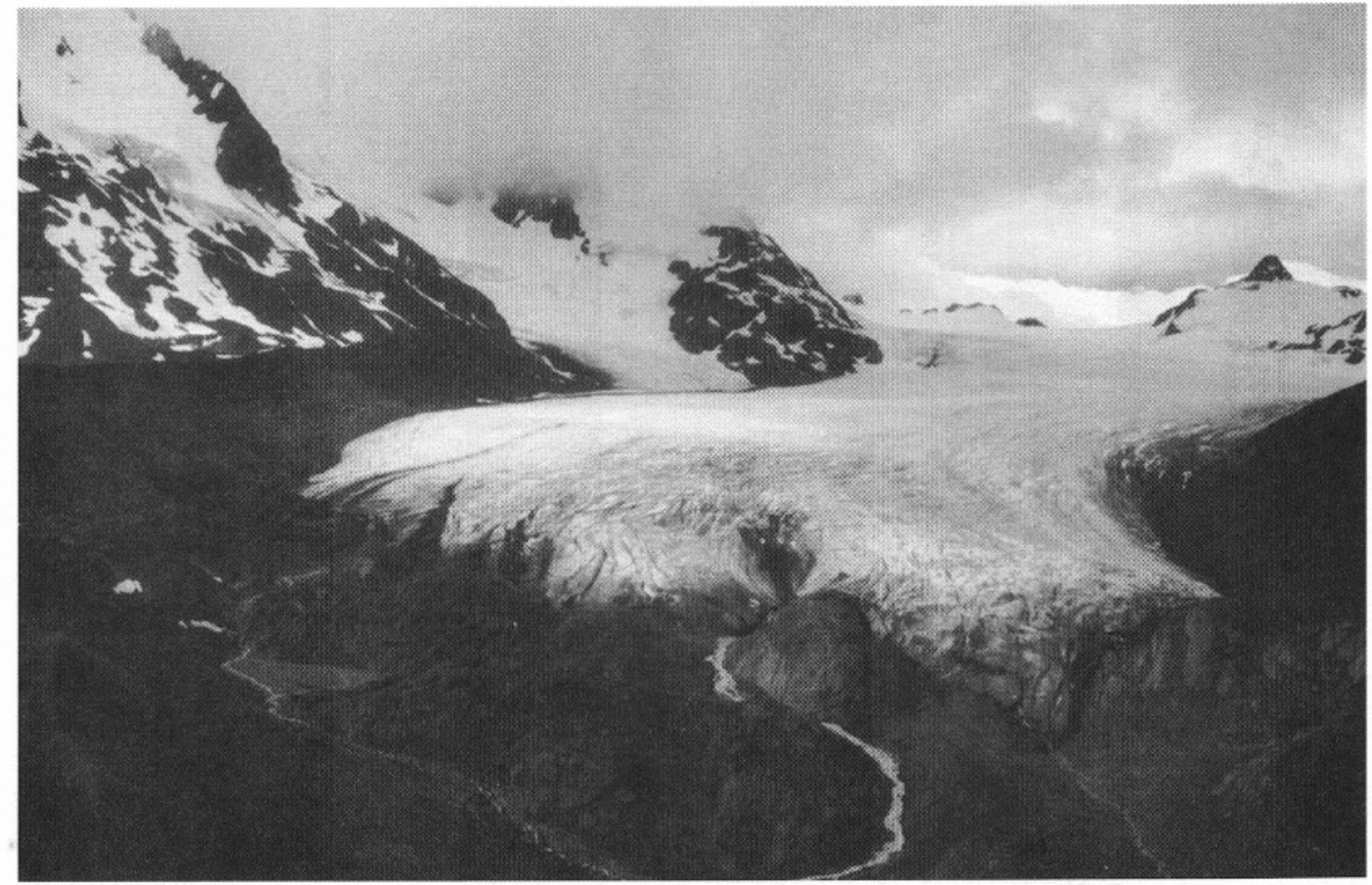

FIGURE 2 - Valley glacier in the Cordillera Darwin of Isla Grande de Tierra del Fuego. 


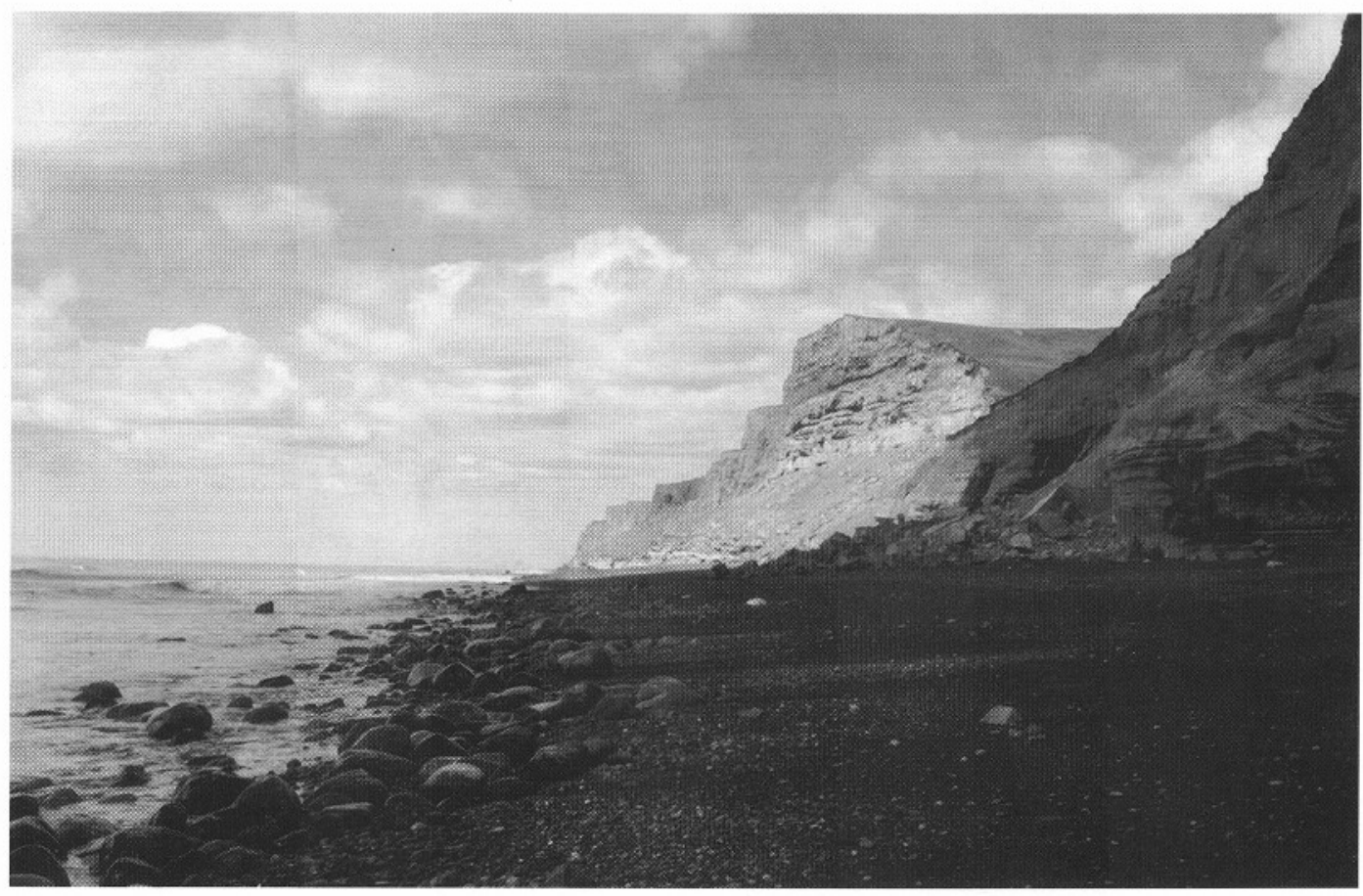

FIGURE 3 - Quaternary deposits overlying Tertiary beds in cliff exposures bordering the Atlantic Ocean in northeastern Argentine sector of Isla Grande de Tierra del Fuego. Note lag boulders, eroded from the glacial drift, at tide level.

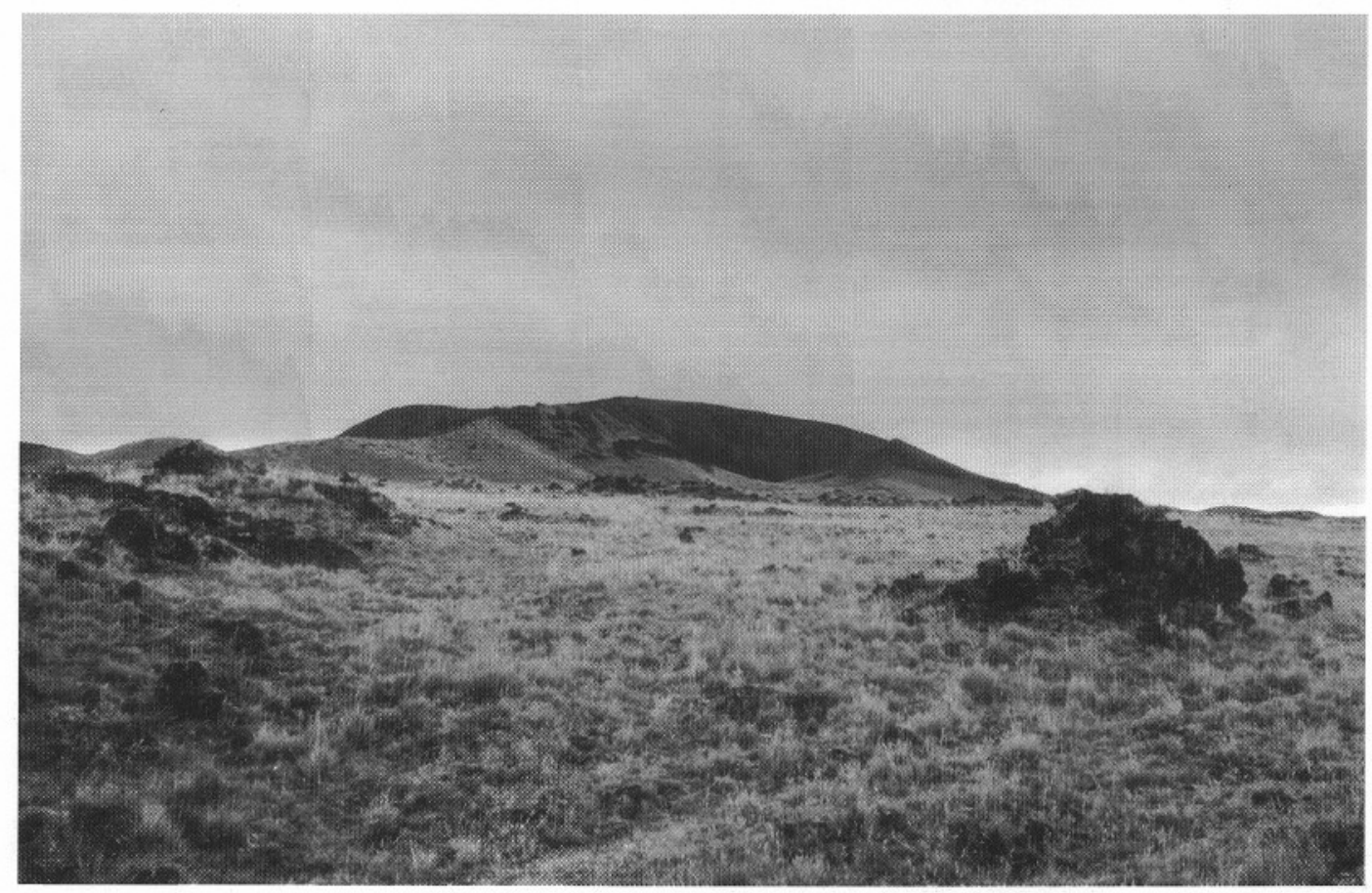

FIGURE 4 - Pleistocene lava flows near Monte Aymond in southeastern Patagonia, volcanic crater in the background. 


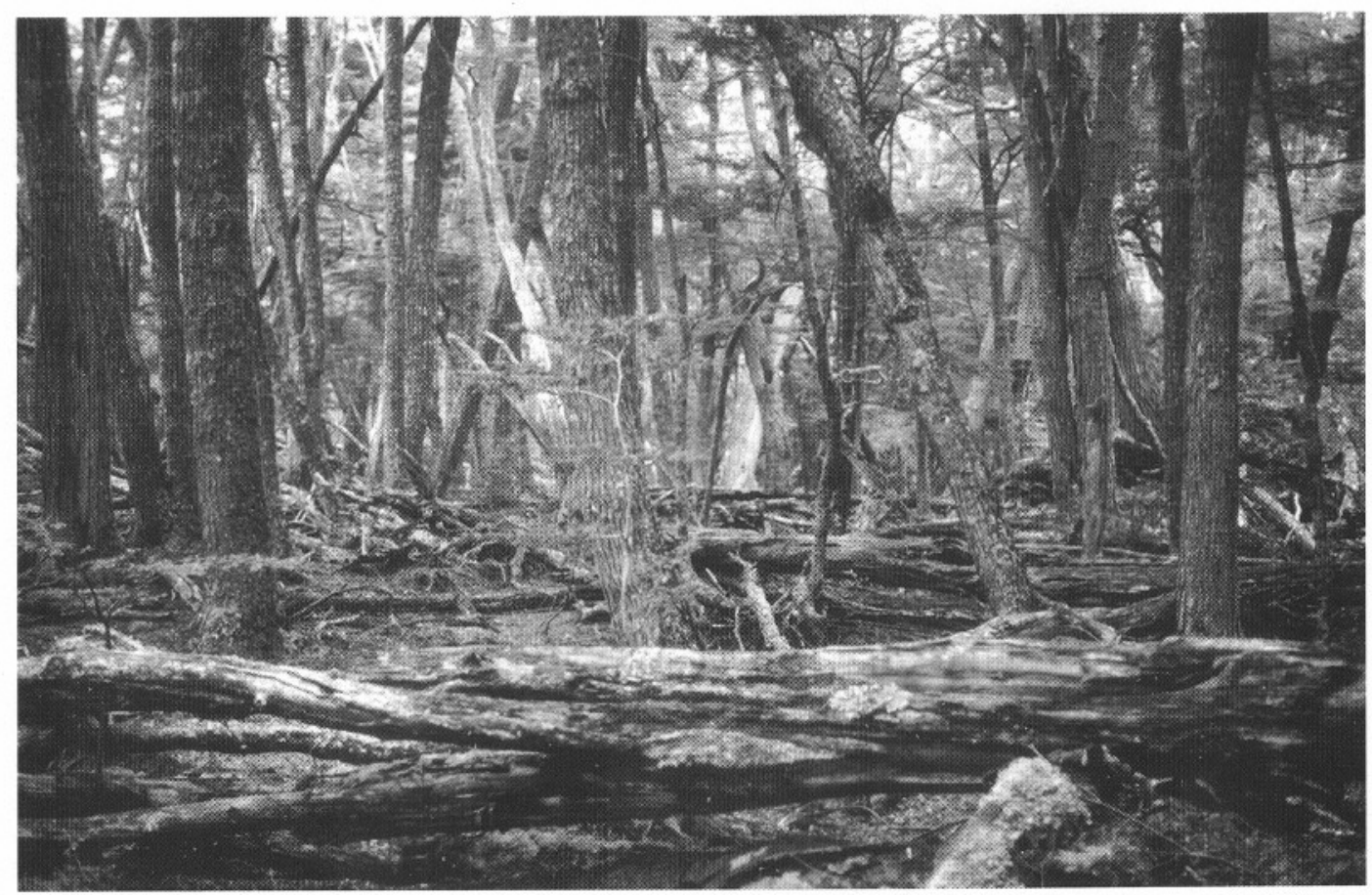

FIGURE 5 - Subantarctic Deciduous Forest principally of Nothofagus pumilio on Isla Grande de Tierra del Fuego.

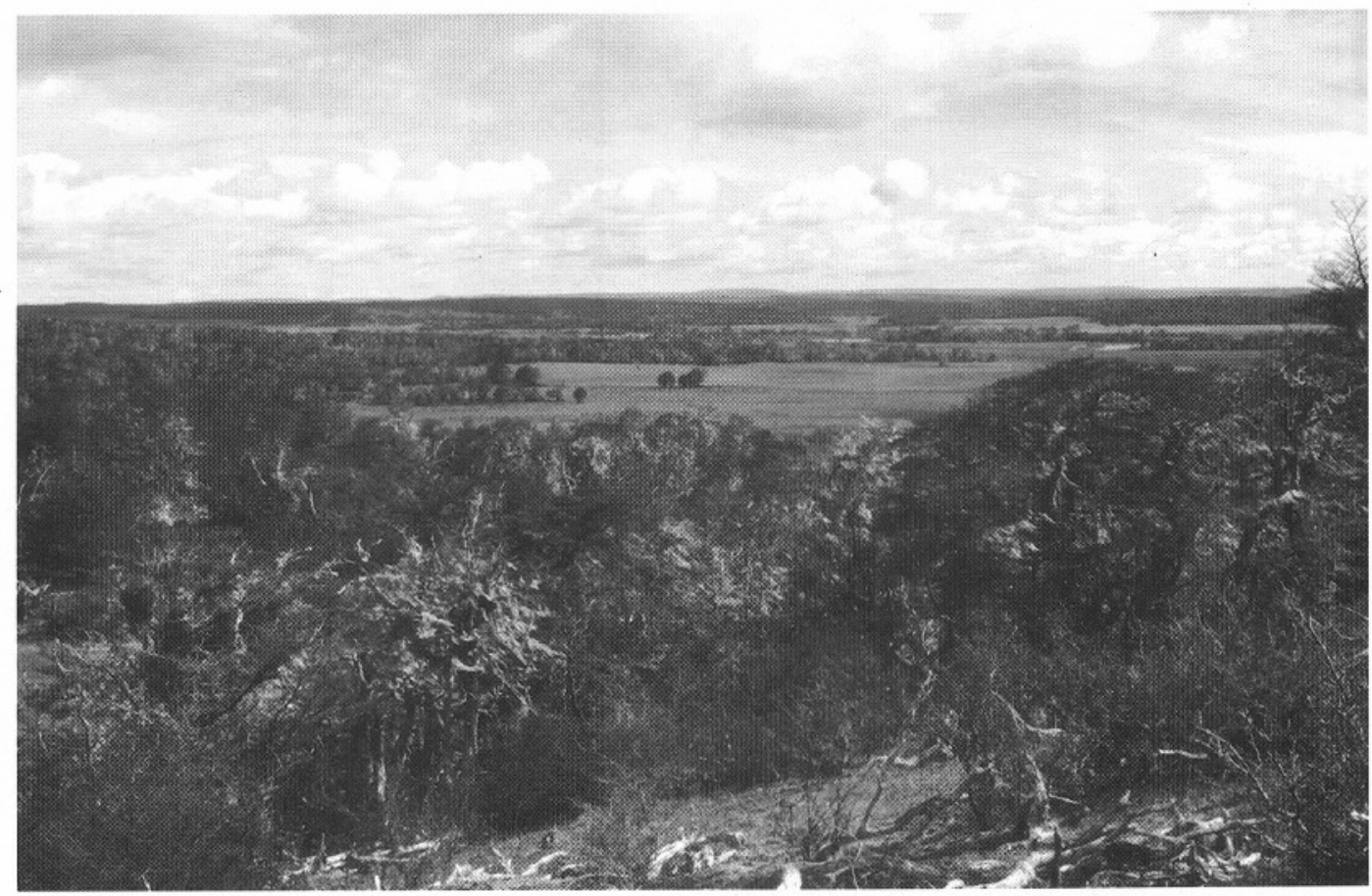

FIGURE 6 - Woodland of Nothofagus antarctica making contact with the steppe at Onamonte in the upper drainage of Río Grande, Chile. 


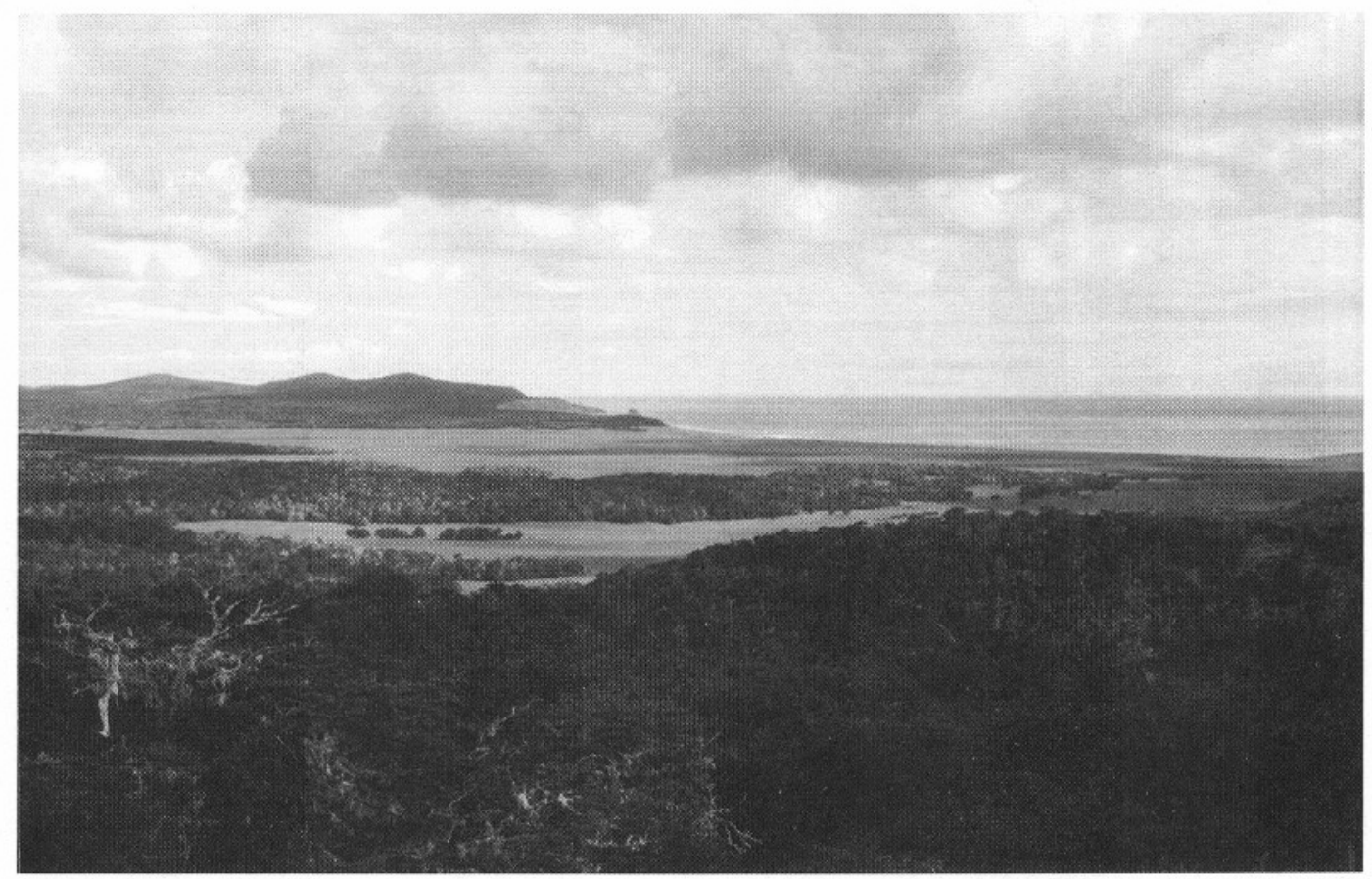

FIGURE 7 - Edge of the Subantarctic Deciduous Forest on the Atlantic coast near Cabo San Pablo, Argentina.

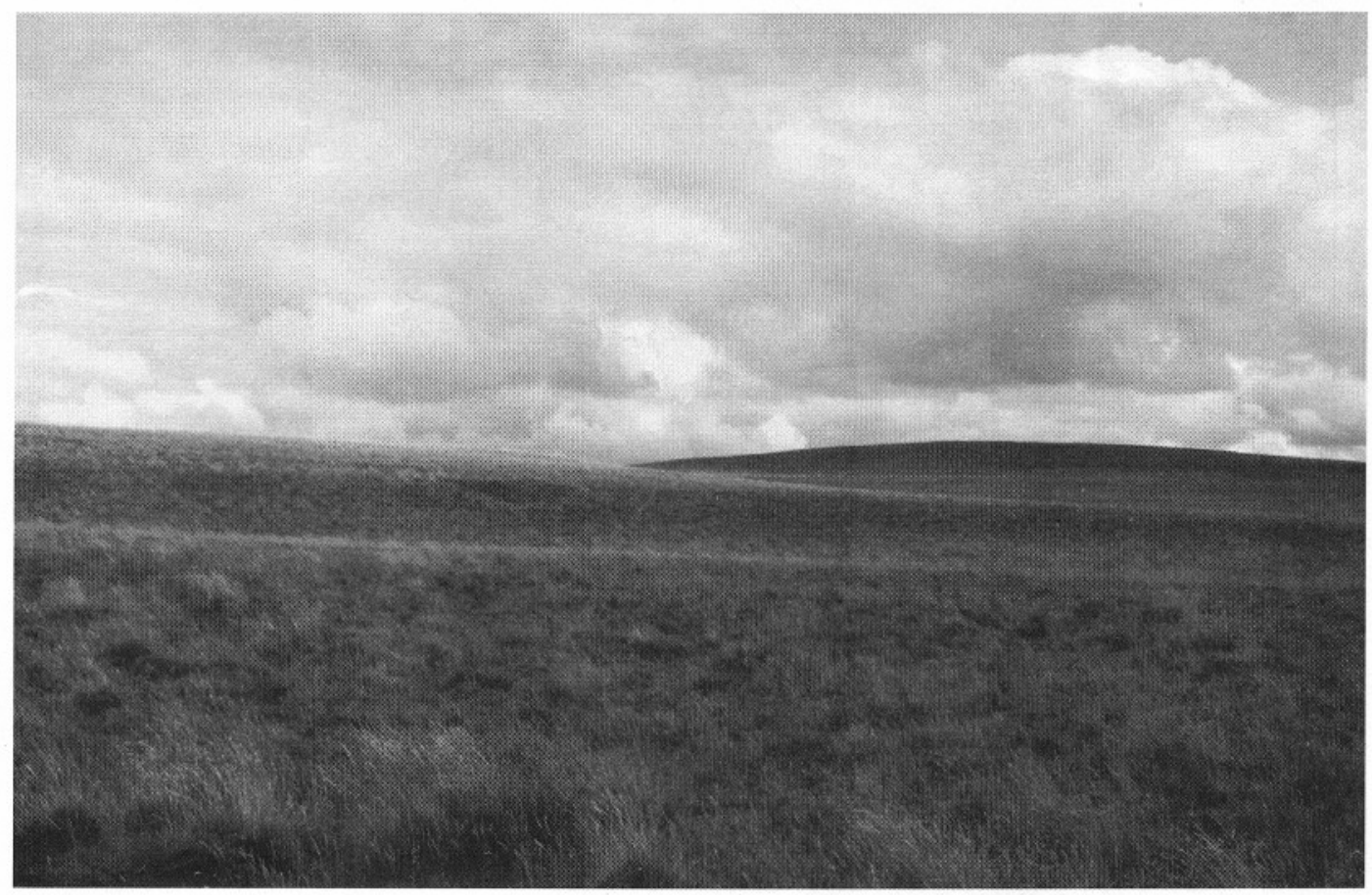

FIGURE 8 - Grass steppe in Argentine Tierra del Fuego. 
through the Estrecho de Magallanes and the Bahía Inútil-Bahía San Sebastian branch and eastward, along the axes provided by Lago Fagnano and Canal Beagle (Fig. 9). MEGLIOLI (1992) estimated an age of around $2 \mathrm{Ma}$ for the oldest Río Grande Drift, located in the vicinity of Río Grande on the Atlantic shore; younger Sierra de los Frailes and Cabo Virgines Drifts, deposited by lobes that reached beyond the present-day entrance of the Estrecho de Magallanes, were dated from ${ }^{40} \mathrm{~A} /{ }^{39} \mathrm{Ar}$ ages on basalt flows below and above the drifts, respectively, $1.07 \pm 0.03-1.4 \pm 0.1$ $\mathrm{Ma}$ and $1.07 \pm 0.03 \mathrm{Ma}-450000 \mathrm{yr} \mathrm{BP}$.

Periglacial features, including ice wedge casts and polygonal ground formed in the older glacial deposits (Fig. 10 and 11), indicate mean annual temperatures of around $-6^{\circ} \mathrm{C}$, or some $12-13^{\circ} \mathrm{C}$ lower than the annual mean of $6.7^{\circ} \mathrm{C}$ today. According to MEGLIOLI (1992), the temperatures, sufficiently low to form ice wedges and polygons, developed following the earliest three of six glaciations evident in FuegoPatagonia. At times of glaciation, heightened continentality, resulting from the enlarged land mass of southern South America, when sea level was lower, contributed to the temperature extremes. An exposed continental shelf extended the continent some $800 \mathrm{~km}$ eastward to beyond the Islas Malvinas (Falkland Islands).

At the last glacial maximum, glaciers reached to the Segunda Angostura in the Estrecho de Magallanes and beyond the shores of Bahía Inútil (Fig. 9; PORTER et al., 1992). Granitic erratics (Fig. 12) derived from the Cordillera Darwin attest to the source of the ice among rock from the core of the Andes. The culmination of the outermost advance of the ice, estimated at around $21000 \mathrm{yr}$ BP at Lago Llanquihue $\left(41^{\circ} \mathrm{S}\right)$ in Chile (LOWELL et al., 1995), is not well constrained in Fuego-Patagonia. PORTER et al. (1992) place the time of the maximum at $>16600 \mathrm{yr}$ BP. Dates of $16590 \pm$ 320 and $15800 \pm 200 \mathrm{yr}$ BP for basal organics in a mire at Puerto del Hambre (Fig. 9) limit the age of earliest deglaciation. Younger dates (no younger than $11900 \mathrm{yr}$ BP at Pampa Alegre) apparently relate to the cessation of meltwater discharge, melting out of locally emplaced ice bodies, drainage of proglacial lakes, or termination of deposition of wind-blown silt.

The glacial chronology along the axis of Canal Beagle - Canal Moat and in the trough of Lago Fagnano (Fig. 9) in the southern part of Isla Grande is likewise only partially established. Moraines along Canal Moat infer the eastern limit of the ice front at $>14640 \mathrm{yr}$ BP (RABASSA et al., 1989a). This timing derives from the age of a mire at Puerto Harberton, situated some $50 \mathrm{~km}$ inside the limit. Glacial retreat westward occurred later at Ushuaia and Lapataia, after 14640 and before $10000 \mathrm{yr}$ BP, and in interior valleys before 9700 and $9300 \mathrm{yr}$ BP (HEUSSER \& RABASSA, 1987; C.J. Heusser, unpublished data). To the north in the Onamonte - Lago Fagnano sector, onset of deglaciation is dated $>11600 \mathrm{yr}$ BP and apparently continued until around 10000 yr BP (HEUSSER, 1993a)

\section{PALYNOLOGY AND PALEOECOLOGY}

Paleoecological reconstructions in FuegoPatagonia stem mostly from records of fossil pollen in radiocarbon-dated deposits applicable to the time of deglaciation following the last glacial maximum. Records chosen serve to illustrate paleoenvironments of discrete geographical regions over extended time spans. Pollen and spore types shown in frequency (\%) diagrams, depicting sequences of the vegetation over the times of record, are mainly of dominant taxa. Categorized as trees, shrubs and herbs, and in a single instance as aquatics and cryptogams, the types are morphologically identifiable chiefly at the family or genus level (HEUSSER, 1971); recognition of species in Nothofagus, for example, has proven to be uneliable. Pollen counts/level are $\mathrm{N}=300$ of trees, shrubs, and herbs, excluding aquatic pollen and spores of cryptogams. For plant nomenclature, reference is made to MOORE (1983).

Evidence of fire in the records is indicated by concentrations of charcoal particulates. Charcoal, represented by scorched or blackened, plant cellular remains, in opposition to amorphous, black mineral material, is recorded by its total area $\left(\right.$ microns $\mathrm{s}^{2} \mathrm{~cm}^{-3}, 7-120$ micron range) measured in each sample.

\subsection{Lago Fagnano Delta}

The palynological record at Lago Fagnano, the oldest of its kind on Isla Grande, traces the Pleistocene glaciodeltaic environment at about 40000 and $>58000$ yr BP (BUJALESKY et al., 1994). The proglacial delta $\left(5^{\circ} 35^{\prime} \mathrm{S}, 6^{\circ} 20^{\prime} \mathrm{W}\right)$ is exposed at the southeastern end of the $100-\mathrm{km}$ long, drowned glacial valley, where at present Subantarctic Deciduous Forest is established (Fig. 9). Cliffs as much as $40 \mathrm{~m}$ in height expose in section the bottomset, foreset, and topset beds of the delta over a horizontal distance of $400 \mathrm{~m}$ (Fig. 13). Evident from overlying glacial drift, the delta predates the last glaciation at the site. 
Steppe-tundra vegetation at the time of delta formation is indicated by the fossil pollen/spores (Fig. 14), which are preserved in biogenic lacustrine horizons in the topset beds exposed in two stream cuts (Section 6 , a $75-\mathrm{cm}$ thick horizon, and Section 8, two horizons, respectively, 60 and $17 \mathrm{~cm}$ in thickness). Shrubs and herbs, represented by Gramineae (grass), Empetrum (heath), and Tubuliflorae (composite), are most frequent, in addition to less frequent Caryophyllaceae, Acaena, and Gunnera; trees exclusively of Nothofagus are minimal. Of local importance are Ranunculaceae, Cyperaceae (sedge), and Myriophyllum, plants of shallow water basins, and Littorella, a near-shore mud inhabitant. Changes in pollen/ spore frequency from level to level evidently are measures of community alteration in response to variable edaphic moisture and the effect of wind.

The implication of the data, which is striking when comparison is made with the local pollen rain at present $(90 \%$ or more of Nothofagus), is of a colder and drier, interstadial, Pleistocene climate. Temperatures for the steppe-tundra setting are estimated to average on the order of $3-5^{\circ} \mathrm{C}$ lower in summer and annual precipitation about $300 \mathrm{~mm}$ less (HEUSSER, 1989a); today summer temperature at Lago Fagnano averages around $10^{\circ} \mathrm{C}$ and precipitation about $500 \mathrm{~mm}$ (TUHKANEN, 1992).

\subsection{Puerto Harberton}

The raised mire at Puerto Harberton

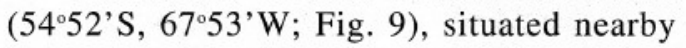
Subantarctic Deciduous - Evergreen Forests (Nothofagus pumilio and $N$. betuloides) and dating nearly $15000 \mathrm{yr}$ BP in age, contains the longest continuous pollen record (Fig. 15) of late-glacial vegetation on Isla Grande (RABASSA et al., 1989a; HEUSSER, 1989b, 1990a). Sediments in the basin of the mire, $>10$ $m$ deep, began accumulating after the ice front in Canal Beagle had withdrawn west of the site.

Pollen stratigraphy of a section covering virtually five millennia of the late-glacial earlier than 10000 yr BP shows Nothofagus, important in the beginning, supplanted subsequently by Gramineae and Empetrum rubrum, indicating the spread of tundra, at first of dwarf shrub heath and later of grass. Peak percentages of Nothofagus at around 11700 and minimal values at 13000 and $10200 \mathrm{yr}$ BP imply fluctuations in community strength, particularly the marked reduction of Nothofagus during the 11100 - 10200 yr BP interval.

After 10000 yr BP, Nothofagus (increasing to $>50 \%$ ) is of greater importance in the record, its assemblage until about $5000 \mathrm{yr} \mathrm{BP}$ with large quantities of Gramineae reflecting a steppe element and open woodland; openness is also inferred by peak presence of the shadeintolerant Filicinae (ferns). Repeated episodes of fire, evident from the significant concentrations of charcoal, occur throughout the early Holocene. It seems likely that fire, as an ecological factor, may have contributed to the open character of the communities.

The last five millennia are given over largely to Nothofagus at levels frequently of $>75 \%$, signifying the overwhelming development of closed forest at the expense of grassland during the late Holocene. Concurrently, mire expansion is implied by the values of Empetrum rubrum and by the excessive amount of peat accumulation ( $5.8 \mathrm{~m}$ compared with 2.2 $\mathrm{m}$ during the early Holocene), except that compaction at depth needs to be taken into consideration. The high rate of accumulation during the interval appears to be a regional trend (RABASSA et al., 1989b).

Late-glacial climate was apparently milder and more mesic before 13000 yr BP at Puerto Harberton. Subsequently, conditions grew colder and drier, while fluctuating at about 11700 before becoming coldest between 11100 and $10200 \mathrm{yr}$ BP. This latest cold episode of Younger Dryas age, when average summer temperature is estimated at $>3^{\circ} \mathrm{C}$ lower than present, is variously recorded in FuegoPatagonia (HEUSSER, 1993b). During the early Holocene along Canal Beagle, climate became warmer than today by an estimated 1$2^{\circ} \mathrm{C}$ with at least $100 \mathrm{~mm}$ less annual precipitation. In the cooler, wetter late Holocene, temperature appears to have varied by $\pm 0.5^{\circ} \mathrm{C}$ and precipitation by $\pm 100 \mathrm{~mm}$ compared with today.

\subsection{Lago Fagnano}

This section of mire at Lago Fagnano $\left(54^{\circ}\right.$ 34'S, 67'37'W; Fig. 9) offers a comparison of pollen/vegetation/climatic sequences on the drier Atlantic and wetter Pacific slopes. Dating from $10800 \mathrm{yr}$ BP, the Lago Fagnano record (Fig. 16; C. J. Heusser, unpublished data) is shortened and covers about four millennia less than at Puerto Harberton; otherwise, where the sequences overlap, both records are remarkably similar. The early Holocene at Lago Fagnano, following limited coverage of the late-glacial, shows comparable increase of Nothofagus, paralleling a decline of the Gramineae, and a singular peak of charcoal. Late Holocene omnipresence of Nothofagus is again evident, as is the increase in peat accumulation $(2.55 \mathrm{~m}$ 


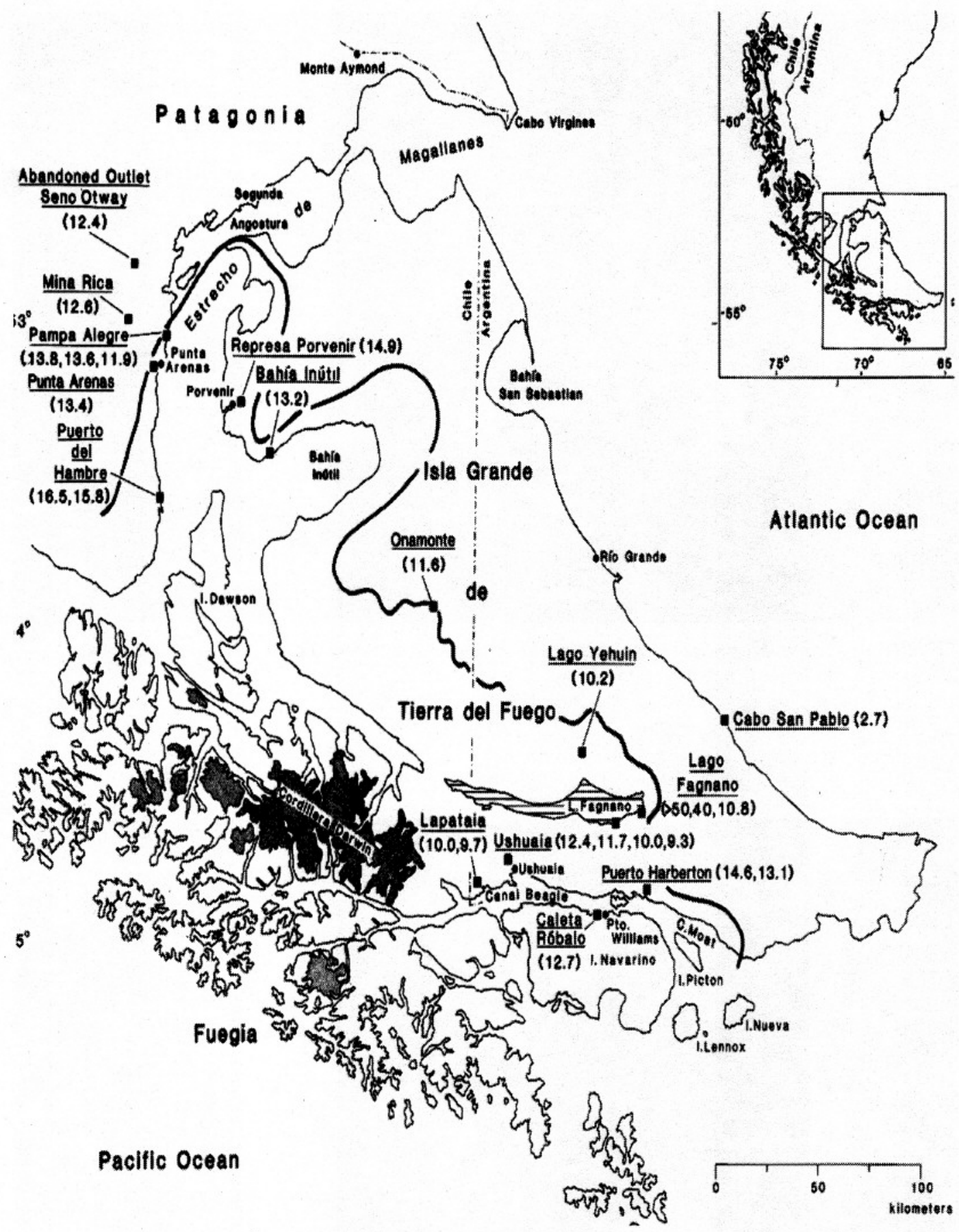

FIGURE 9 - Extent of glaciation on Isla Grande de Tierra del Fuego during the last glacial maximum, shown approximately by heavy solid line. Lobes advanced in the Estrecho de Magallanes, Bahía Inútil, Lago Fagnano, and Canal Beagle. Existing areas of glaciers, notably in the Cordillera Darwin, are indicated by stippling. Study sites with radiocarbon dates (x $10^{3} \mathrm{yr}$ BP) appear underlined. See text for sources. 


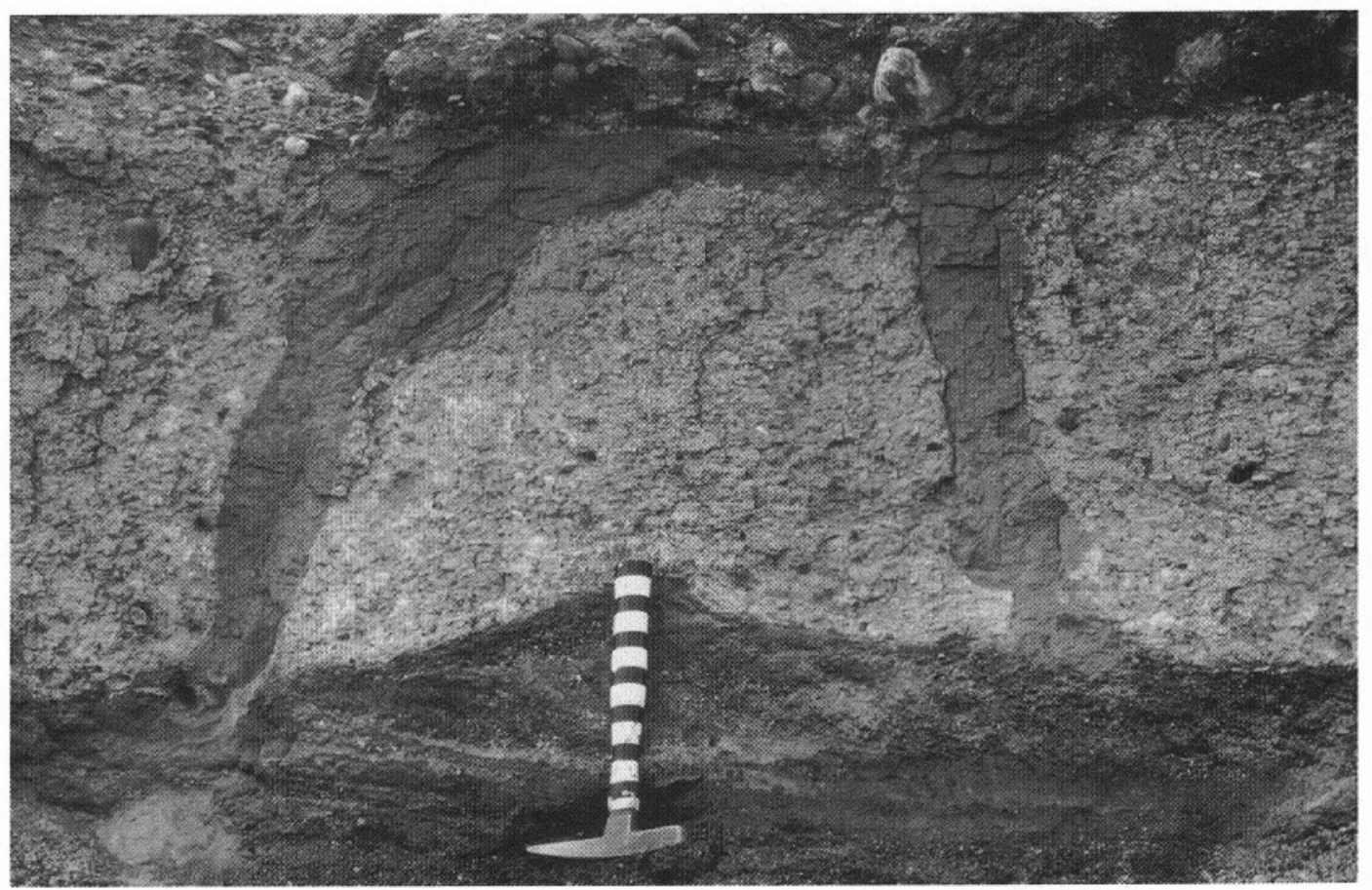

FIGURE 10 - Ice-wedge casts in Cabo Virgines Drift near Monte Aymond in southeastern Patagonia.

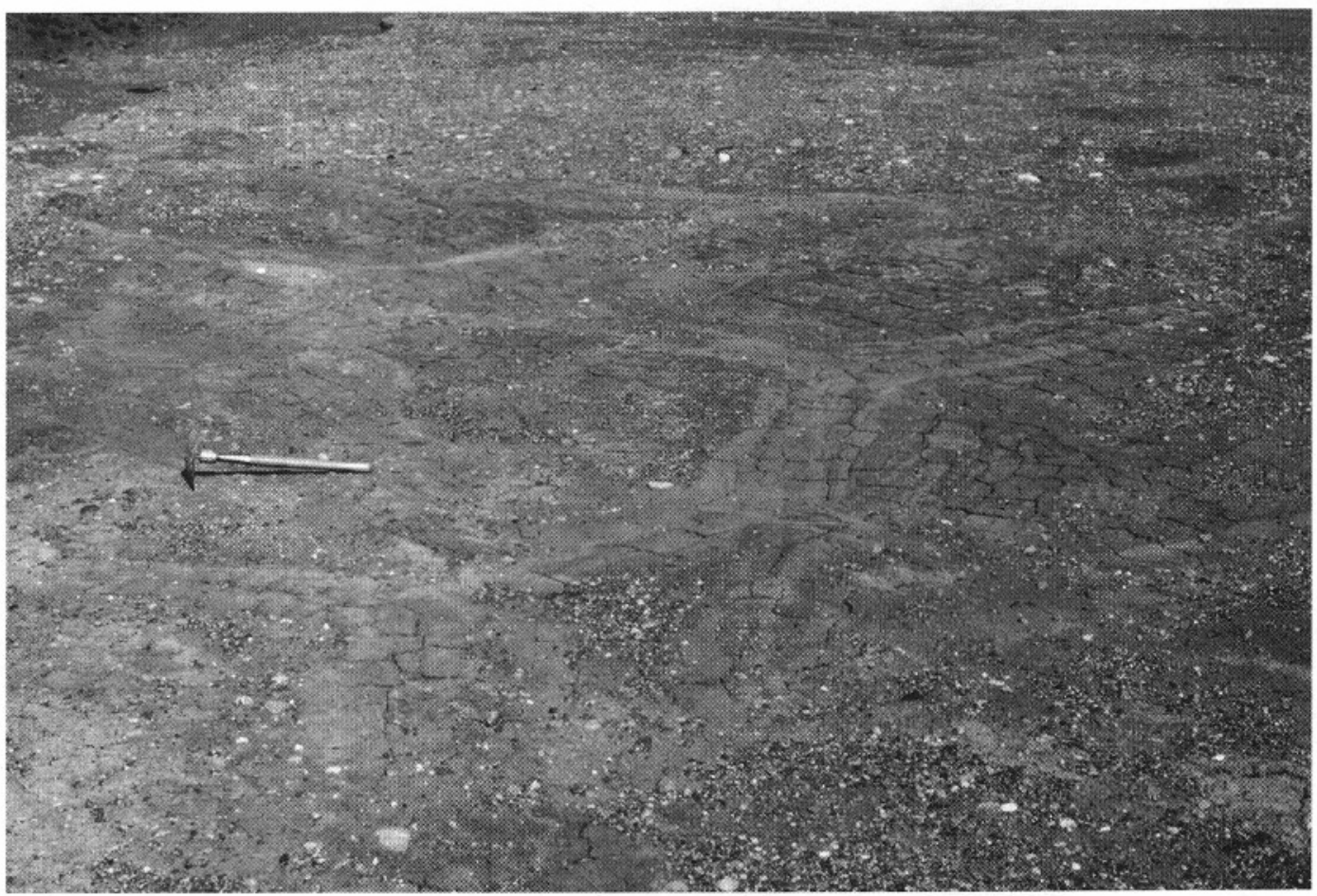

FIGURE 11 - Periglacial patterned ground in southeastern Patagonia. 


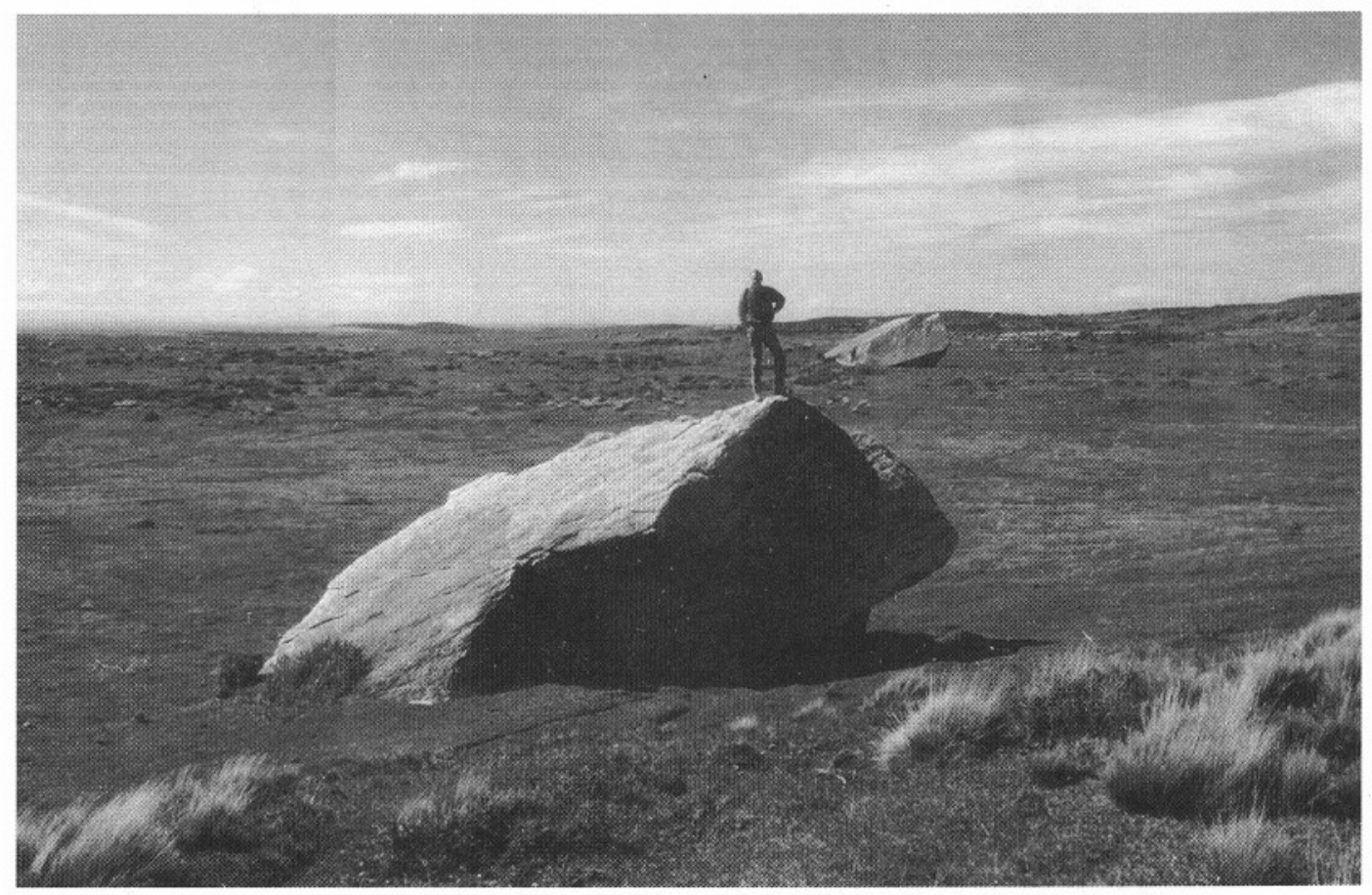

FIGURE 12 - Granite erratics, glacially transported from the core of the Andes in the Cordillera Darwin, weathering out of drift along the southern border of Bahía Inútil, Isla Grande.

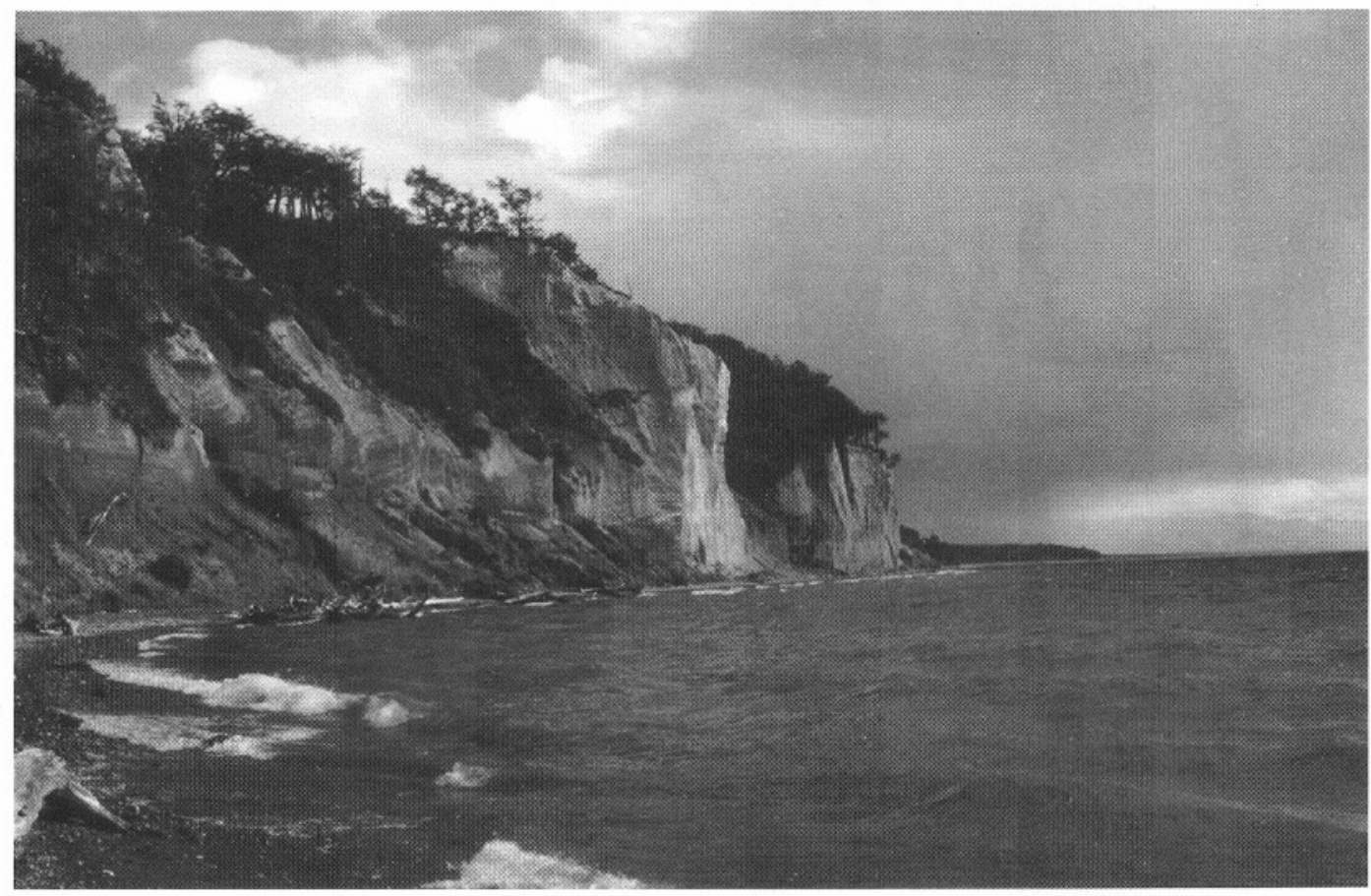

FIGURE 13 - Proglacial delta exposed at the southeastern end of the drowned glacial valley of Lago Fagnano. Bottomset, foreset, and topset beds of the delta are visible in the cliff face. The delta predates overlying drift of the glacial maximum. 


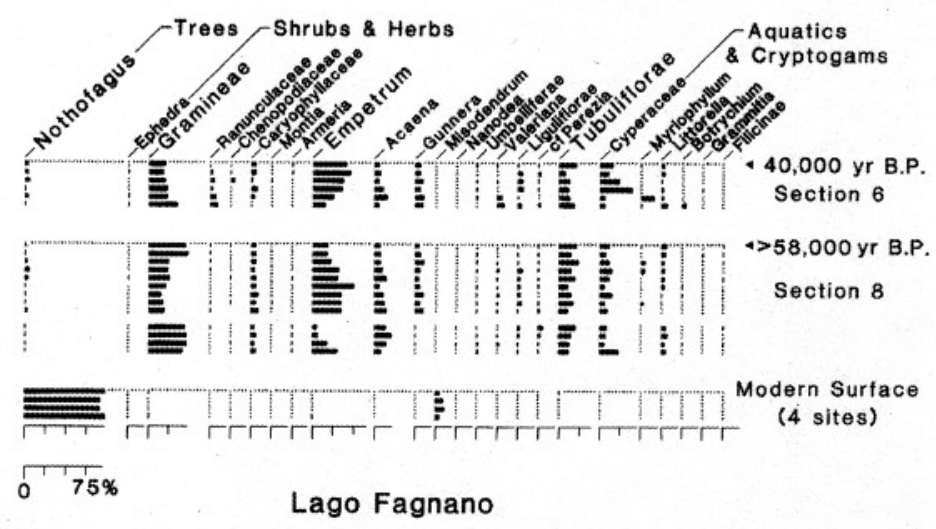

FIGURE 14 - Pollen-spore diagram of biogenic lacustrine sediments exposed in topset beds of the proglacial delta at Lago Fagnano. Fossil spectra in sections 6 and 8 are compared with modern spectra at four nearby sites located in Subantarctic Deciduous Forest. Noteworthy taxa are indicated by enlarged type.

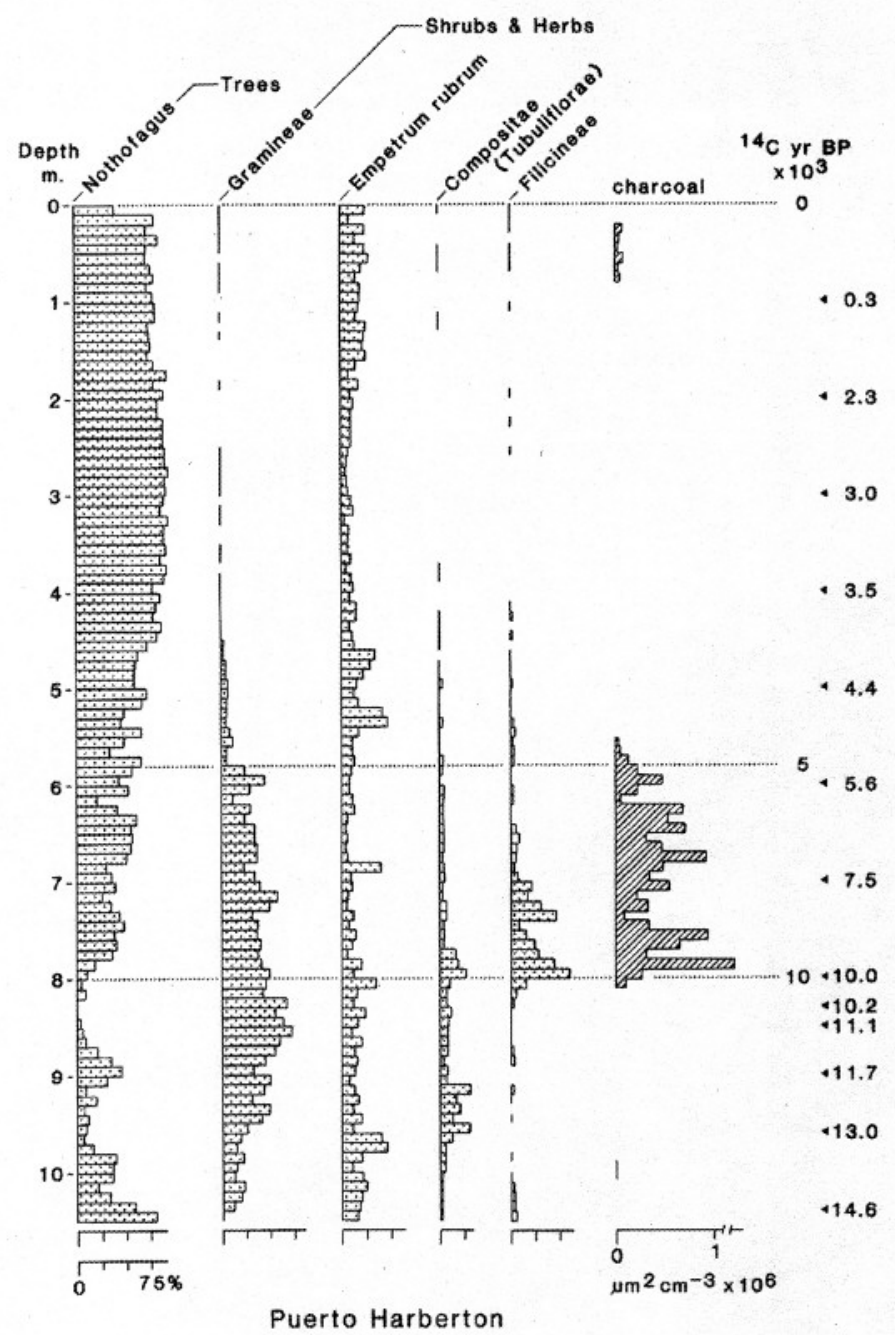

FIGURE 15 - Diagram of principal pollen-spore taxa shown in relation to charcoal in the mire section at Puerto Harberton, Argentina (redrawn from HEUSSER, 1994). 


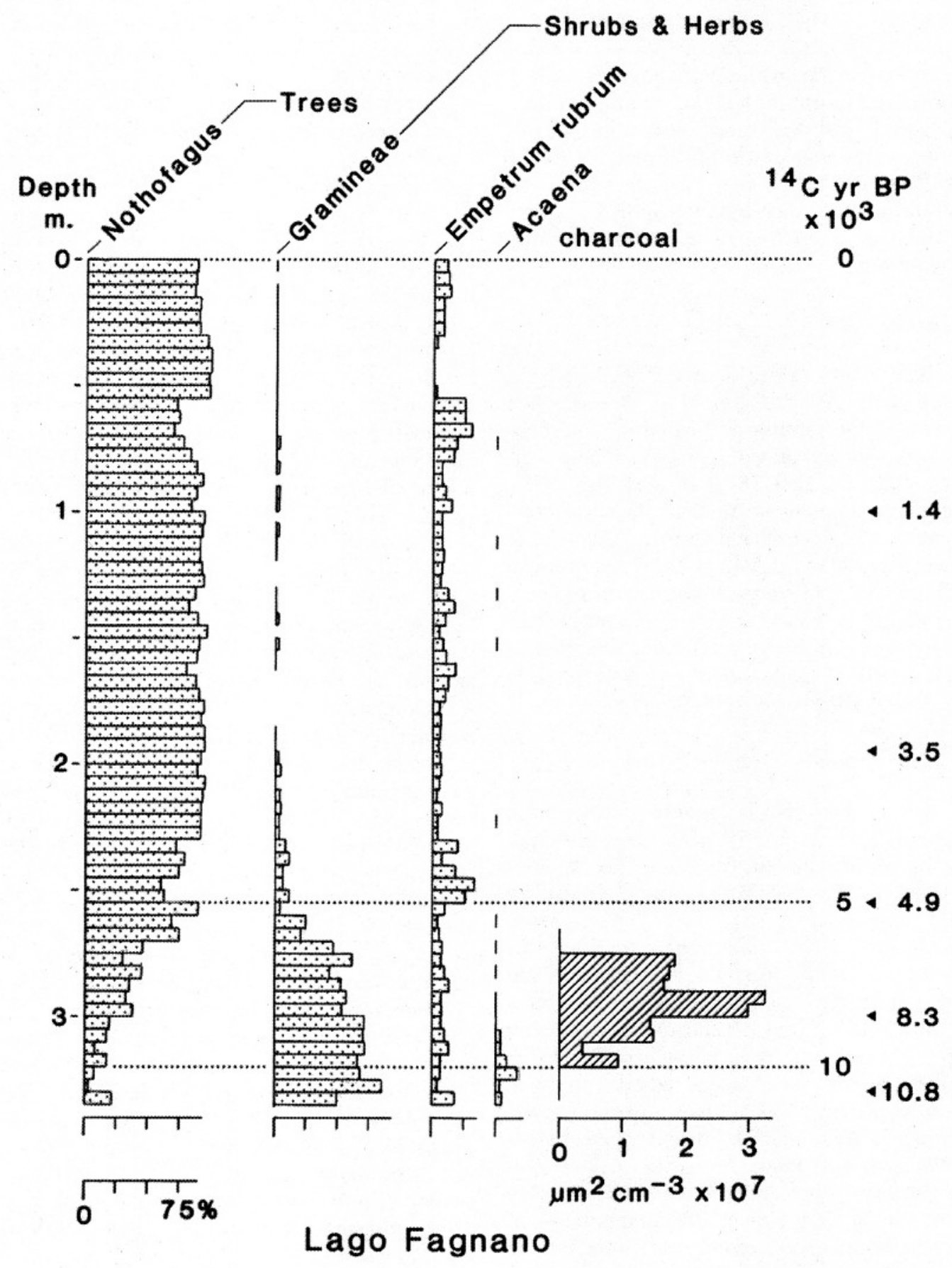

FIGURE 16 - Diagram of principal pollen taxa and charcoal in the section of mire at Lago Fagnano, Argentina (redrawn from HEUSSER, 1994). 
in comparison with $0.65 \mathrm{~m}$ during the early Holocene).

Thus, development of vegetation on both sides of the Andean cordillera, where implied by comparable pollen data, apparently proceeded under the same climatic control. Closed Nothofagus forest displaced steppe grassland at Puerto Harberton, while Nothofagus similarly invaded and supplanted the steppe at Lago Fagnano. Forest dominance on the upland, following abatement of fire, was reached in the late Holocene under cooler, more humid climate, which also increased the spread of mires and their cover of Empetrum rubrum on lowlying terrain.

\subsection{Bahía Inútil}

Bahía Inútil (53⒉ $7^{\prime} \mathrm{S}, 70^{\circ} 06^{\prime} \mathrm{W}$ ), located in steppe on the Atlantic slope (Fig. 9), is a pollen sequence representing peat horizons interbedded with clay and gravel in proglacial lake sediments (Fig. 17; HEUSSER et al., 1989-1990). The record supplements the late-glacial of Lago Fagnano (Fig. 16) by providing data from between 13280 and $12010 \mathrm{yr} \mathrm{BP}$, which show a high proportion of steppe elements and apparent long-distance, wind-transported quantities of Nothofagus. The large amount of charcoal at $13280 \mathrm{yr}$ BP is the earliest major concentration thus far recorded in Fuego-Patagonia.

\subsection{Punta Arenas}

The first of two Patagonian sites, Punta

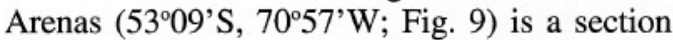
of mire in Subantarctic Deciduous Forest close to the Estrecho de Magallanes. Spanning $>13400$ years (Fig. 18), the pollen sequence (HEUSSER, 1995) approaches the length of time of the section from Puerto Harberton and covers millennia encompassed at Lago Fagnano (Figs. 14 and 15). Correlation of Holocene events is evident from the chronostratigraphy of all three pollen and charcoal records, implying common paleoecological control of the vegetation. For the late-glacial, however, percentages of Nothofagus at Punta Arenas are overall proportionately higher and amounts of Gramineae lower than at Harberton, a reflection possibly of the importance of Acaena plotted at Punta Arenas (Acaena at Puerto Harberton was far less important, and for that reason is not included in the pollen diagram).

While trends upward in the late-glacial, showing a decrease of Nothofagus and increase of Gramineae, are basically similar, the fluctuations evident in Nothofagus at Harberton are not discernible at Punta Arenas. The reason for this difference may be attributed to local paleoenvironmental influence on Nothofagus pollen production/preservation. At Punta Arenas, the episode of cooler climate of Younger Dryas age evident at Puerto Harberton is not recognizable, underscoring the variability of the forcing-vegetation/pollen response relationship of the Younger Dryas climatic event in southern South America (HEUSSER, 1993b).

\subsection{Torres del Paine}

The 10800 yr BP section from a summerdry lake surrounded by Patagonian Steppe in the vicinity of Torres del Paine $\left(50^{\circ} 59^{\prime} \mathrm{S}\right.$, $72^{\circ} 40^{\prime} \mathrm{W}$; Fig. 1) provides, by virtue of its long, 8.5-m record (Fig. 19), an expanded version of the Holocene (HEUSSER, 1995). Rate of deposition of the lake sediments was apparently fairly uniform; except at mid-section, where a rapid increase $\left(4.28 \mathrm{yr} \mathrm{cm}^{-1}\right)$ is indicated by the $2.8 \mathrm{~m}$ of sediments formed in 1200 years betwen 7500 and $6300 \mathrm{yr}$ BP.

The early Holocene, covering $5.8 \mathrm{~m}$ of the section, shows at first the rise of Nothofagus to $>25 \%$ before $7500 \mathrm{yr}$ BP, followed successively by diminution, secondary increase of Nothofagus to just under $50 \%$ close to $6000 \mathrm{yr} \mathrm{BP}$, and lastly, a repetition of general diminution. The Gramineae, together with Acaena and Compositae (Tubuliflorae), are throughout dominant, and reach their greatest proportion of $>75 \%$ at near-surface levels, following a rising trend beginning around $3700 \mathrm{yr}$ BP. Pollen of Nothofagus at Torres del Paine evidently has been wind-transported from extralocal forest/ woodland. There remains the possibility, however, that intervals with higher percentages of Nothofagus may be indicative of communities of forest/woodland developed locally in the past.

Fire, reflected by the incidence of charcoal, is in evidence at all levels in the section and increasingly so, both early and late in the Holocene. The influence of fire in shaping the vegetation, however, is not clear from the evidence. Fire at the beginning of the record seems to follow the decline of the Gramineae, suggesting burning of the steppe, whereas the rise of Gramineae later is possibly caused by fire limiting woodland/forest.

\section{FOREST - STEPPE BOUNDARY}

Pollen profiles of the Torres del Paine section contain no indication of a major shift in the forest/steppe boundary, induced by climate, fire, biota, or other factor, over the time of 


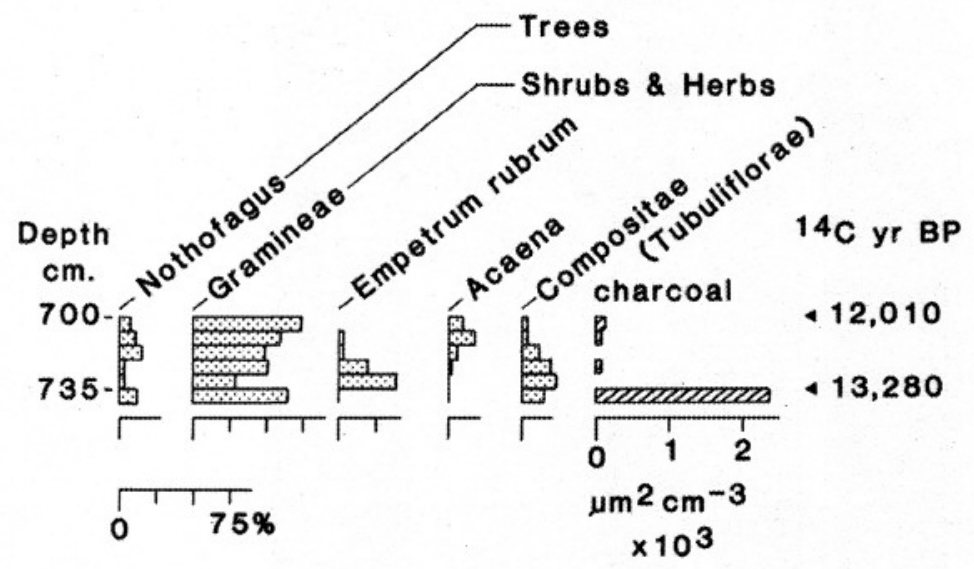

\section{Bahía Inútil}

FIGURE 17 - Diagram of major pollen taxa and charcoal in the lacustrine sequence at Bahía Inútil, Chile (redrawn from HEUSSER, 1994).

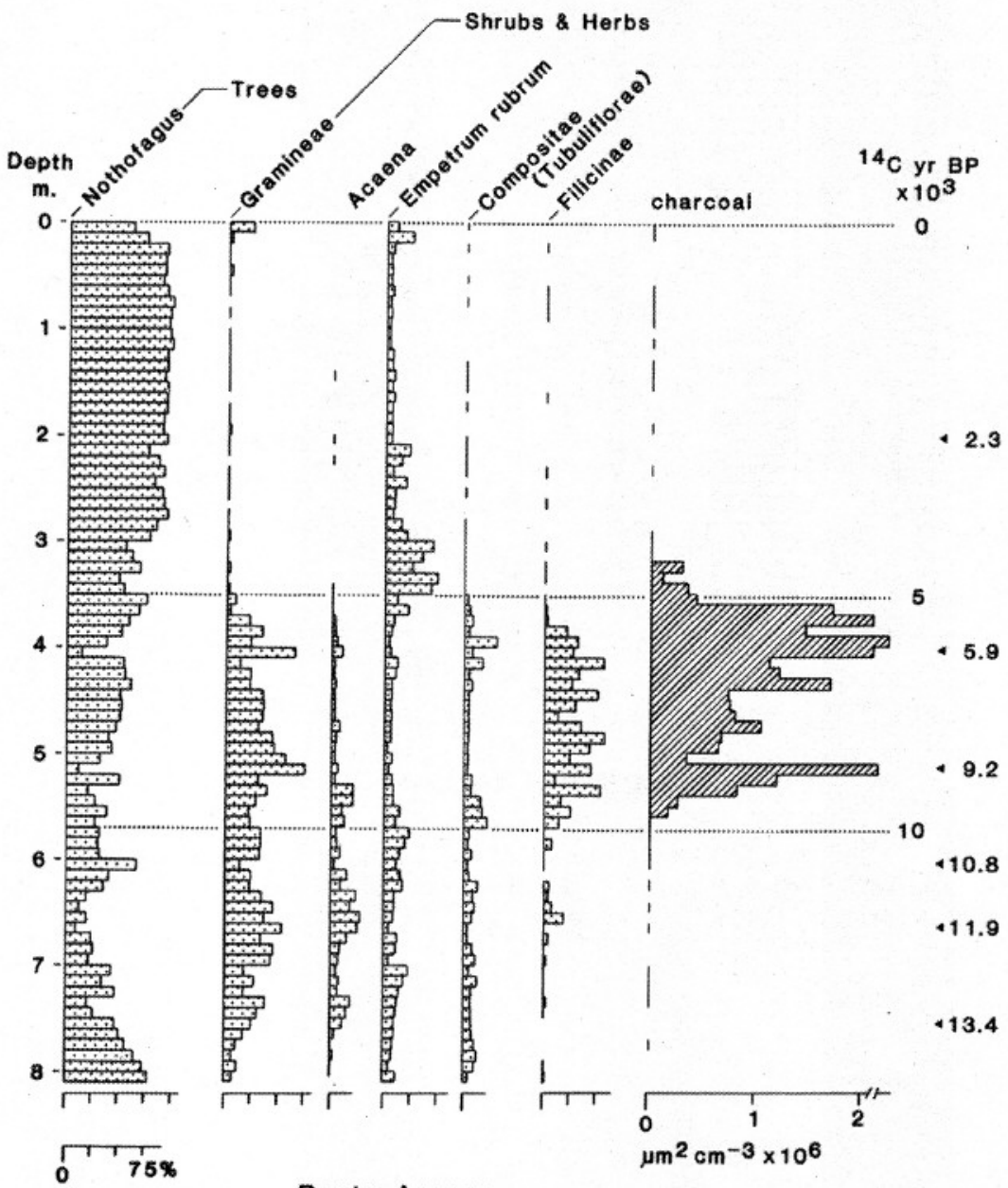

Punta Arenas

FIGURE 18 - Diagram of principal pollen-spore taxa and charcoal in the mire section at Punta Arenas, Chile (redrawn from HEUSSER, 1994). 


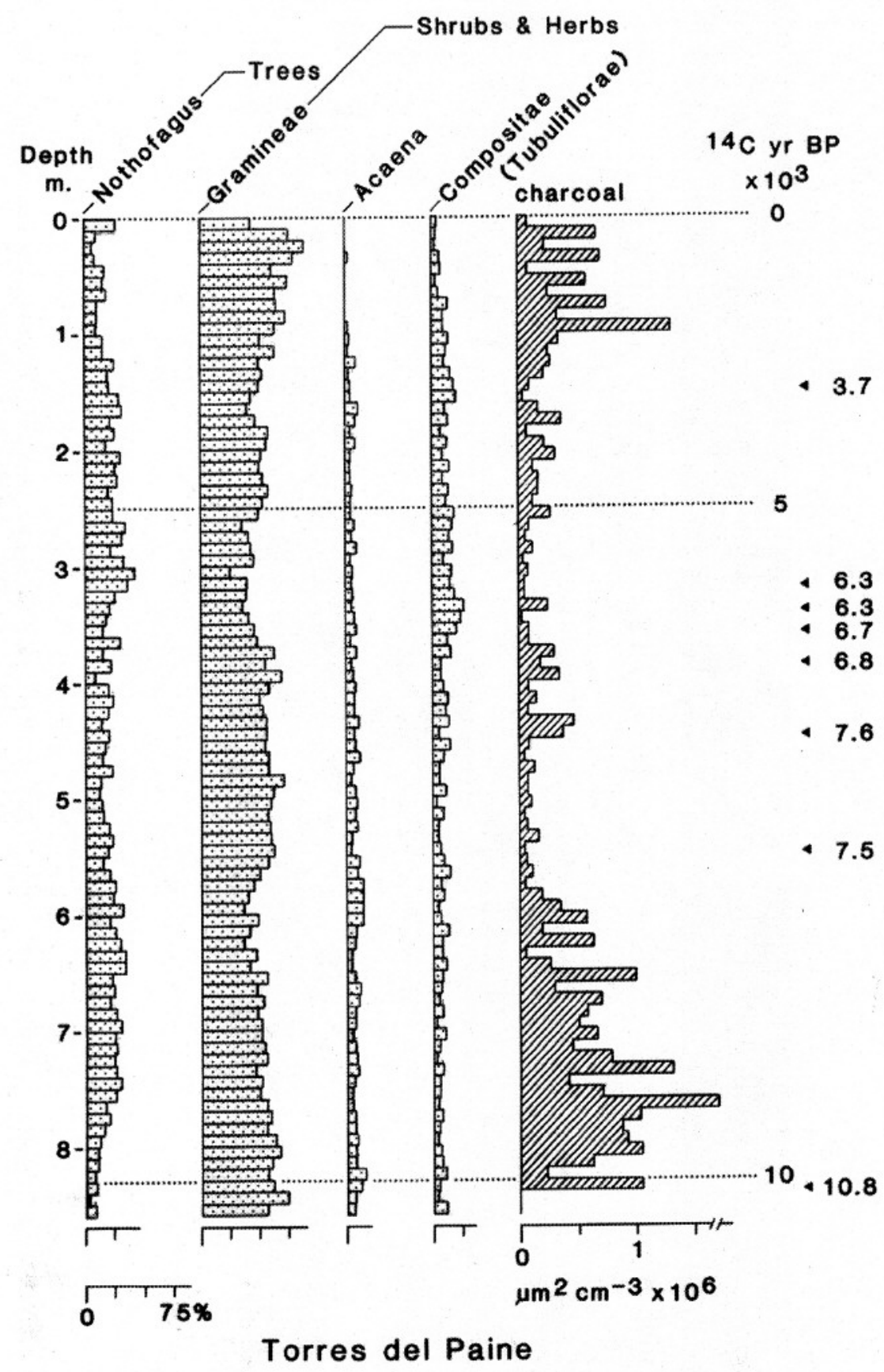

FIGURE 19 - Diagram of principal pollen taxa and charcoal in the section of limnic sediments from the summer-dry lake at Torres del Paine, Chile (redrawn from HEUSSER, 1994).. 
record. Stands of Nothofagus are at present locally established within kilometers of the section site (PISANO, 1974), but conditions apparently have remained restrictive and prevented their late Holocene enlargement on the scale seen at Punta Arenas, Lago Fagnano, and Puerto Harberton. In this regard, it is probable that cold, limited soil moisture, and wind have played important roles in the altitudinal setting of the Paine cordillera.

Pre-13000 yr BP importance of Nothofagus is noted at Punta Arenas and Puerto Harberton (Figs. 15 and 18), followed afterward in the late-glacial by steppe, or steppetundra, including Gramineae, Acaena, Empetrum, and Compositae (Tubuliflorae). Steppe persisted in the early Holocene at these sites and at Lago Fagnano (Fig. 16), gradually being displaced ultimately by forest communities. On the Atlantic slope of the Fuegian Andes, enclaves of Nothofagus, possibly refugial in the late-glacial, were sources of trees that were present later in the forest-steppe contact zone.

Holocene migration of trees toward the Atlantic, as recorded at sites on Isla Grande (Fig. 9), has proved to be irregular (HEUSSER, 1993c). Maximal percentages of Nothofagus, implying the presence of forest, were reached at Lago Fagnano by $5000 \mathrm{yr}$ BP, but not until after 1500 yr BP at Onamonte (HEUSSER, 1993a), and only during the past millennium at Cabo San Pablo (HEUSSER \& RABASSA, 1994). While fire appears to have been instrumental in effecting irregular advance of the treeline, greater intensity/frequency of oceanic storms of the prevailing westerlies, following paths shifting northeastward over the last 5000 years, is primarily held accountable for forests on the Atlantic slope.

\section{PALEOINDIANS AND FIRE}

Where lightning and volcanism, as possible causes of fire, can be eliminated in nonvolcanic regions virtually unaffected by lightning, charcoal in Quaternary deposits can serve to establish the presence, age, and migratory routes of Paleoindians (HEUSSER, 1987, 1994). This premise is especially applicable to the charcoal record found on nonvolcanic Isla Grande de Tierra del Fuego with a record of negligible lightning; thunderstorms, with the possibility of lightning, average $<1 \mathrm{day}^{-1}$ at Ushuaia (Fig. 9), according to PROHASKA (1976). Strong convective movement in vertical columns of air of considerable altitude, required for thunderstorms (and lightning) to take place, are not a meteorological feature of Fuego-Patagonia because of the low temperatures, poor radiational heating at the ground level, and shearing effect of the powerful prevailing westerlies.

Fire served Paleoindian hunters with a means of gathering and corraling animals for a kill. At times, uncontrolled, burning undoubtedly consumed large tracts of vegetation. Charcoal at Bahía Inútil (Fig. 17) with an age of $13280 \mathrm{yr}$ BP represents the earliest recorded conflagration on Isla Grande. It predates the oldest, $12600 \mathrm{yr}$ BP, Paleoindian lithic industry in southern Patagonia (CARDICH et al., 1973), as well as charcoal at as much as $12390 \mathrm{yr} \mathrm{BP}$ in regional cave deposits (NAMI, 1987; MASSONE, 1987; BORRERO et al., 1988). Dated between 13500 and 12500 yr BP, the earliestknown human presence in southern South America is at Monte Verde in south-central Chile (DILLEHAY, 1989). From charcoal evidence, however, it may be on the order of 50000 years old in subtropical central Chile (HEUSSER, 1990b).

It is easy to conceive that Paleoindian hunters migrated from Patagonia to Isla Grande via Bahía Inútil. Arrival on Isla Grande was possibly by way of a land connection at Segunda Angostura, which is about $80 \mathrm{~km}$ north of Bahía Inútil (Fig. 9), during the lateglacial when sea level was lower than now. Migration by $10000 \mathrm{yr}$ BP had proceeded to the southern part of the island, as inferred by the earliest concentrations of charcoal in sections at Lago Fagnano and Puerto Harberton (Figs. 15 and 16). Younger concentrations in sections from Onamonte and Cabo San Pablo (Fig. 9; HEUSSER, 1993a; HEUSSER \& RABASSA, 1994) infer Paleoindian proximity much later during recent millennia.

Not incompatible with the general trend shown by these data is archeological evidence of human occupation dated 11880 and $10280 \mathrm{yr}$ BP at Tres Arroyos, located between Bahía Inútil and Bahía San Sebastian, in north-central Isla Grande (MASSONE, 1987). In the south of the island, on the other hand, charcoal peaking at about $10000 \mathrm{yr} \mathrm{BP}$ at Puerto Harberton is considerably older than the earliest occupation at around $7000 \mathrm{yr} \mathrm{BP}$ of the archeological site at Túnel, just east of Ushuaia (ORQUERA \& PIANA, 1987). The latest charcoal at Túnel is dated at $450 \mathrm{yr} \mathrm{BP}$; together with records at ages of $380 \mathrm{yr}$ BP and younger at both Puerto Harberton and Caleta Róbalo (Fig. 9; HEUSSER, 1989a), the evidence extends human presence in settlements along Canal Beagle to modern times. 


\section{CONCLUSIONS}

Treeless steppe-tundra under cold, dry climate was apparently a feature of the Atlantic slope of Fuegia during Pleistocene interstades. Stadial vegetation, beyond glacier margins in the Pleistocene, was increasingly sparse in a frigid antarctic setting. Ice-age southern South America, while sea level was lower with much of the Atlantic shelf exposed, lay transformed into an enlarged, wind-swept, and mostly barren land mass subject to increased continentality.

Vegetation during the late-glacial consisted of developing woodland, limited in extent largely on the Pacific slope and broken by predominantly steppe-tundra. Reflected are milder, more mesic climatic episodes, interrupted by intervals of relative cold and dryness. Wood- land expansion and displacement of steppe, giving rise to structurally closed forest, characterize the Holocene. Paleoindian hunters, known to have been active in Patagonia as early as the late-glacial, are believed to be responsible for burning of the vegetation, which is particulary evident from widespread charcoal in Holocene deposits.

\section{ACKNOWLEDGMENTS}

Data in the course of these studies were gathered with support from the National Science Foundation (USA), Consejo Nacional de Investigaciones Científicas y Técnicas (Argentina), Empresa Nacional del Petróleo and Servicio Nacional de Geología y Minería (Chile), and National Geographic Society.

\section{BIBLIOGRAPHY}

AUER, V. 1933. Verschiebungen der Waldund Steppengebiete Feuerlands in postglazialer Zeit. Acta Geographica 5: 1-313. 1956. The Pleistocene of FuegoPatagonia. Part I. The ice and interglacial ages. Annales Academiae Scientiarum Fennicae III. Geologica-Geographica 45: 1-226.

1958. The Pleistocene of FuegoPatagonia. Part. II. The history of the flora and vegetation. Annales Academiae Scientiarum Fennicae III. GeologicaGeographica 50: 1-239.

1974. The isorhythmicity subsequent to Fuego-Patagonian and Fennoscandian ocean level transgressions and regressions of the latest glaciation. Annales Academiae Scientiarum Fennicae III. Geologica-Geographica 115: 1-88.

BORRERO, L.; LANATA, J.L. \& BORELLA, F. 1988. Reestudiando huesos: nuevas consideraciones sobre sitios de Ultima Esperanza. Anales del Instituto de la Patagonia 18: 133-156.

BUJALESKY, G.; HEUSSER, C. J.; CORONATO, A.; ROIG, C. \& RABASSA, J. 1994. Pleistocene glaciodeltaic environment at Lago Fagnano, Tierra del Fuego, southernmost South America (543ㅇ's). Unpublished manuscript.

CALDENIUS, C.C. 1932. Las glaciaciones cuaternarias en la Patagonia y Tierra del Fuego. Geografiska Annaler 14: 1-164.

CAMINOS, R. 1980. Cordillera Fuegiana. Segundo Simposio de Geología Regional
Argentina. Academia Nacional de Ciencias de Córdoba II: 1463-1501.

CARDICH, A.; CARDICH, L. A. \& HAJDUK, A. 1973. Secuencia arqueológica y cronología radiocarbónica de la Cueva 3 de Los Toldos (Santa Cruz, Argentina). Relaciones de la Sociedad Argentina de Antropología 7: 85-123.

CODIGNOTTO, J. O. \& MALUMIAN, N. 1981. Geología de la región al norte del paralelo $54^{\circ} \mathrm{S}$ de la Isla Grande de Tierra del Fuego. Revista Asociación Geológica Argentina 36: 44-88.

DILLEHAY, T. D. 1989. An evaluation of the environmental reconstruction and the human presence at Monte Verde. In: Monte Verde. A Late Pleistocene Settlement in Chile (T. D. Dillehay, ed.), pp. 227-250. Smithsonian Institution Press, Washington, D. C.

HEUSSER, C. J. 1971. Pollen and spores of Chile. Modern types of the Pteridophyta, Gymnospermae, and Angiospermae. University of Arizona Press, Tucson.

1987. Fire history of FuegoPatagonia. Quaternary of South America and Antarctic Peninsula 5: 93-109.

1989a. Late Quaternary vegetation and climate of southern Tierra del Fuego. Quaternary Research 31: 396-406.

1989b. Climate and chronology of Antarctica and adjacent South America over the past 30000 yr. Palaeogeography, Palaeoclimatology, Palaeoecology 76: 31-37. 
HEUSSER, C.J. 1990a. Late-glacial and Holocene vegetation and climate of subantarctic South America. Review of Palaeobotany and Palynology 65: 9-15.

$1990 \mathrm{~b}$. Ice age vegetation and climate of subtropical Chile. Palaeogeography, Palaeoclimatology, Palaeoecology 80: 107-127.

1993a. Late Quaternary forest steppe contact zone, Isla Grande de Tierra del Fuego, subantarctic South America. Quaternary Science Reviews 12:169-177.

1993b. Late-glacial of southern South America. Quaternary Science Reviews 12:345-350.

1993c. Climate, fire, and forest steppe interaction in Tierra del Fuego during the Quaternary. Program and Abstracts International Workshop the Quaternary of Chile, 39.

1994. Paleoindians and fire during the Quaternary in southern South America. Revista Chilena de Historia Natural 67:435-443.

1995. Three Late Quaternary pollen diagrams from southern Patagonia and their palaeocological implications. Palaeogeography, Palaeoclimatology, Palaeoecology (in press).

HEUSSER, C. J.; HEUSSER, L. E. \& HAUSER, A. 1989-1990. A $12000 \mathrm{yr}$ B.P. tephra layer at Bahía Inútil (Tierra del Fuego, Chile). Anales del Instituto de la Patagonia 19: 39-49.

HEUSSER, C. J. \& RABASSA, J. 1987. Cold climatic episode of Younger Dryas age in Tierra del Fuego. Nature 328: 609-611.

1994. Late holocene forest steppe interaction at Cabo San Pablo, Isla Grande de Tierra del Fuego, Argentina. Quaternary of South America and Antarctic Peninsula 9: 179-188.

LOWELL, T. V.; HEUSSER, C. J.; ANDERSEN, B.G.; MORENO, P. I.; HAUSER, A.; DENTON, G. H.; HEUSSER, L. E.; SCHLÜCHTER, C. \& MARCHANT, D. R. 1995. Interhemispheric symmetry of paleoclimatic events during the last glaciation. Science (in press).

MARKGRAF, V. 1993. Palaeoenvironments and palaeoclimates in Tierra del Fuego and southernmost Patagonia, South America. Palaeogeography, Palaeoclimatology, Palaeoecology 102: 53-68.
MASSONE, M. 1987. Los cazadores paleoindios de Tres Arroyos (Tierra del Fuego). Anales del Instituto de la Patagonia 17: 47-60.

MEGLIOLI, A. 1992. Glacial geology and chronology of southernmost Patagonia and Tierra del Fuego, Argentina and Chile. Doctoral dissertation, Lehigh University, Bethlehem, PA.

MERCER, J. H. 1967. Southern Hemisphere glacier atlas. U. S. Army Natick Laboratories Technical Report 67-76-ES.

MOORE, D. M. 1975. The alpine flora of Tierra del Fuego. Anales del Instituto Botánico Antonio José Cavanilles del C. S. I. C. 32: 419-440.

1983. Flora of Tierra del Fuego. Nelson, Oswestry.

NAMI, G. 1987. Cueva del Medio: perspectivas arqueológicas para la Patagonia austral. Anales del Instituto de la Patagonia 17: 73-106.

ORQUERA, L. A. \& PIANA, E. L. 1987. Human littoral adaptation in the Beagle Channel region: the maximum possible age. Quaternary of South America and Antarctic Peninsula 5: 133-162.

PISANO, E. 1974. Estudio ecológico de la región sur del área Andino-Patagónica. II. Contribución a la fitogeografía de la zona del Parque Nacional "Torres del Paine." Anales del Instituto de la Patagonia 5: 59-104.

1977. Fitogeografía de FuegoPatagonia chilena. I. Comunidades vegetales entre las latitudes $52^{\circ}$ and $56^{\circ}$. Anales del Instituto de la Patagonia 8: 121-250.

1981. Bosquejo fitogeográfico de Fuego-Patagonia. Anales del Instituto de la Patagonia 12: 159-171.

PORTER, S. C.; CLAPPERTON, C. M. \& SUGDEN, D. E. 1992. Chronology and dynamics of deglaciation along and near the Strait of Magellan, southernmost South America. Sveriges Geologiska Undersökning 81: 233-239.

PORTER, S. C.; STUIVER, M. \& HEUSSER, C. J. 1984. Holocene sea-level changes along the Strait of Magellan and Beagle Channel, southernmost South America. Quaternary Research 22: 59-67.

PROHASKA, F. 1976. The climate of Argentina, Uruguay, and Paraguay. In: World Survey of Climatology. Vol. 12. Climates of Central and South America. (W. Schwerdtfeger, ed.) pp. 13-112. Elsevier, Amsterdam. 
RABASSA, J.: BUJALESKY, G.; MEGLIOLI, A.; CORONATO, A.; GORDILLO, S.; ROIG, C. \& SALEMME, M. 1992. The Quaternary of Tierra del Fuego, Argentina. Sveriges Geologiska Undersökning 81: 249-256.

RABASSA, J.; HEUSSER, C. J. \& RUTTER, N. 1989a. Late-glacial and Holocene of Argentine Tierra del Fuego. Quaternary of South America and Antarctic Peninsula 7: 327-351.

RABASSA, J.; HEUSSER, C. J. \& CORONATO, A. 1989b. Peat-bog accumulation rate in the Andes of Tierra del Fuego and Patagonia (Argentina and Chile) during the Last 43000 years. Pirineos 133: 113-122.

RABASSA, J.; HEUSSER, C. J. \& STUCKENRATH, R. 1986. New data on Holocene sea transgression in the Beagle Channel, Tierra del Fuego, Argentina. Quaternary of South America and Antarctic Peninsula 4: 291-310.

RUSSO, A.; FLORES, M. A. \& DI BENEDETTO, H. 1980. Patagonia austral extraandina. Segundo Simposio de
Geología Regional Argentina. Academia Nacional de Ciencias de Córdoba 2: 1431-1462.

RUTTER, N.; SCHNACK, E. J.; DEL RIO, J.; FASANO, J. L.; ISLA, F. I. \& RADTKE, U. 1989. Correlation and dating of Quaternary littoral zones along the Patagonian coast, Argentina. Quaternary Science Reviews 8: 213-234.

SCHMITHÜSEN, J. 1960. Die Nädelholzer in den Waldgesellschaften der südlichen Anden. Vegetatio 9: 313-327.

SKOTTSBERG, C. 1910. Übersicht über die wichtigsten Pflanzenformationen Sudamerikas S. von $41^{\circ}$, ihre geographische Verbreitung und Beziehungen zum Klima. Kungl. Svenska Vetenskapsakademiens Handlingar. 46: 1-28.

STERN, C. R. 1990. Tephrochronology of southernmost Patagonia. National Geographic Research 6: 110-126.

TUHKANEN, S. 1992. The climate of Tierra del Fuego from a vegetation geographical point of view and its ecoclimatic counterparts elsewhere. Acta Botanica Fennica 145: 1-64. 